\title{
Demographic Change and Economic Growth in Asia
}

David E. Bloom, David Canning, and Pia N. Malaney

CID Working Paper No. 15

May 1999

(C) Copyright 1999 David E. Bloom, David Canning, Pia N. Malaney, and the President and Fellows of Harvard College

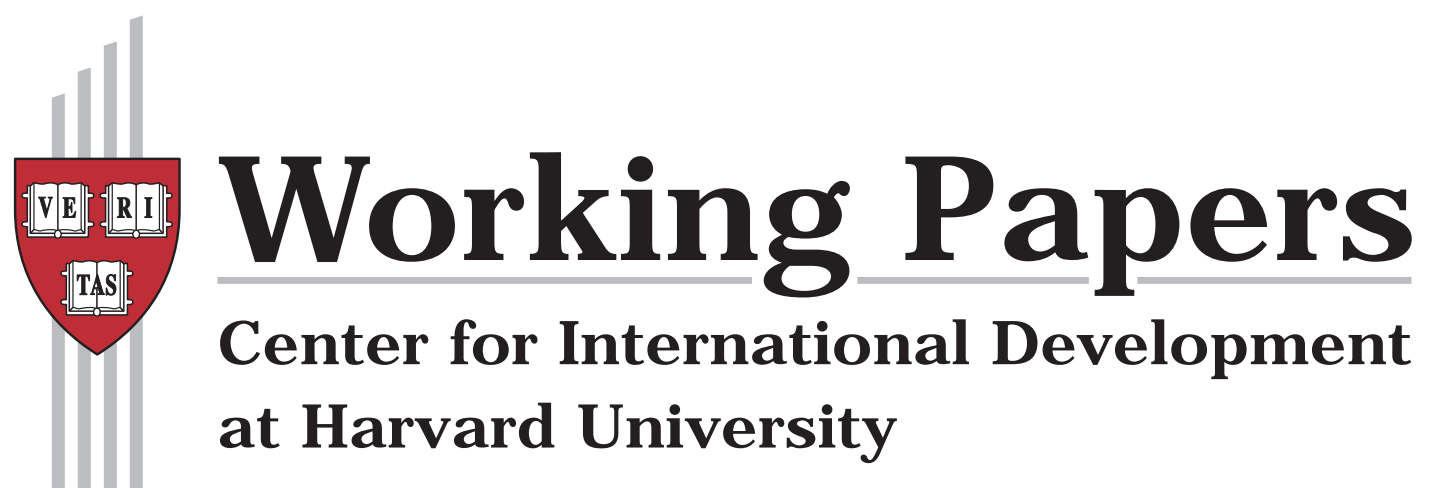




\title{
Demographic Change and Economic Growth in Asia
}

\author{
David E. Bloom, David Canning, and Pia N. Malaney*
}

\begin{abstract}
This paper examines the links between demographic change and economic growth in Asia during 1965-90. We show that the overall rate of population growth had little effect on economic growth, but that changes in life expectancy, age structure, and population density have had a significant impact on growth rates. We also find strong evidence of feedback from higher income to population change via lower fertility, though a significant component of the demographic changes appears to have been exogenous. Our results suggest that the demographic transition can act both as a catalyst and as an accelerator mechanism, and that demographic effects can explain most of East Asia's economic "miracle". East Asia benefited from a "virtuous spiral" of income growth and fertility decline, while South Asia seems to remain caught in a low-level population-income trap.
\end{abstract}

JEL Codes: J10, O40.

Keywords: population, fertility, economic growth

David Bloom is deputy director of HIID, professor of population and health economics at Harvard's School of Public Health, and a Faculty Associate at CID.

Pia Malaney is a Development Associate at Harvard Institute for International Development.

David Canning is a Professor at the Queen's University of Belfast and is visiting the Department of Economics at Harvard University.

\footnotetext{
*An earlier version of this paper was presented at a conference on Economic Aspects of Demographic Transition: The Experience of Asian-Pacific Countries. The conference was held at the Institute of Economics, Academica Sinica, National Taiwan University, June 19-20, 1998. We thank Eric Bettinger, David Evans, Bryan Graham, and Larry Rosenberg for assistance in preparing this paper, and Allen Kelley, Ronald Lee, Andrew Mason, Christine Paxson, and Robert Schmidt for valuable comments. We also thank the U.S. Agency for International Development (USAID) for financial support provided under the Consulting Assistance on Economic Reform II Project, contract number PCE-0405-C-00-5015-00. The views and interpretation in this paper are those of the authors and should not be attributed to the USAID.
} 


\title{
Demographic Change and Economic Growth in Asia
}

\author{
David E. Bloom, David Canning, and Pia N. Malaney
}

\section{Introduction}

East Asia's near tripling of real income per capita during the last 30 years is one of the most extraordinary economic phenomena of this century. Never before has income per capita grown so rapidly in such a large group of countries for such a prolonged period. Several economies in the subregion that began this period as low- or middle-income developing countries are now genuine industrial leaders.

Numerous studies have sought to explain East Asia's economic “miracle." The literature highlights a wide range of possible explanations, including trade and industrial policies, technological progress, savings and capital accumulation, governance, education and health spending, geography and culture, and initial income levels (see, for example, Asian Development Bank 1997; Krugman 1994; Landes 1998; Rodrik 1994, 1998; Sachs and Warner 1995; World Bank 1993; Young 1994, 1995). These studies rely on a variety of conceptual frameworks, statistical methods, and data sources. Although they stress different causal factors, they reach the common conclusion that economic growth in general, and East Asia's unrivalled growth performance in particular, is not a monocausal phenomenon. Economic growth is affected by many factors, whose cumulative effects can account for much of East Asia's superior performance in relation to that of the world economy as a whole during 1965-90, as well as for the relatively poor performance of South Asia and Sub-Saharan Africa. However, even accounting for these influences on economic growth, the literature still finds significant unexplained differences in regional economic performance. East Asia performs better than its 
measured characteristics would otherwise suggest, whereas South Asia and Africa perform worse.

One striking feature of the literature is the generally superficial attention it pays to the influence of demographic factors on economic growth. The standard approach acknowledges the possibility that rapid population growth might impede economic growth by including the rate of population growth among the list of variables used to explain cross-country differences in income growth. More often than not, however, population growth does not emerge as being significantly associated with the pace of economic growth, thereby supporting the conclusion of population neutralism (Bloom and Freeman 1986) that has held sway for nearly two decades (Kelley and Schmidt 1995).

In recent years, investigators have revisited the connection between population and economic growth, emphasizing the demographic transition as the process underlying population growth in most developing countries (Bloom and Canning 1999; Bloom and Freeman 1988; Bloom and Sachs 1998; Bloom and Williamson 1997). The demographic transition is a change from a situation of high fertility and high mortality to one of low fertility and low mortality. The research indicates that high rates of population growth are temporary consequences of the decline in mortality preceding the decline in fertility. Less widely recognized, though perhaps more important, it also suggests sizable changes in the age distribution of the population. These changes occur for two main reasons. First, the initial mortality decline is concentrated among infants and young children, thereby concentrating its effects at the lower end of the age distribution. Second, the subsequent fertility decline has an effect on the age distribution that is, naturally, entirely concentrated at age zero. The combination of these two forces introduces a bulge into the population pyramid. Its leading edge is created by the decline in infant and child 
mortality and its trailing edge by the decline in fertility. Over time, the bulge ages and moves from being concentrated among young people to being concentrated at the prime ages for working, saving, and reproduction, and eventually, to being concentrated at the years of old age.

The young and the old tend to consume more output than they generate, unlike workingage individuals, whose contribution to output and to savings (see Higgins 1998, Higgins and Williamson 1997; Kelley and Schmidt, 1996, Lee, Mason, and Miller 1998, Leff 1969, Mason 1988, and Webb and Zia 1990) tends to be more than commensurate with their consumption. As a result, the value of output per capita-the most widely used indicator of economic performance-tends to be boosted when the population of working-age individuals is relatively large, and tends to be depressed when a relatively large part of the population consists of young and elderly dependents. In addition, a fall in the youth dependency ratio permits schooling per child to rise, adding further to future economic growth. ${ }^{1}$

As the population age distribution changes over the course of a demographic transition and beyond, levels of income per capita will change correspondingly, revealing patterns of economic growth that have proven to be robustly evident in cross-national data. Indeed, age structure changes appear to account for a remarkably high share of cross-country differences in rates of income growth. For example, demographic change accounts for as much as a third to a half of the mystery surrounding the sustained high rates of income growth that came to be known as the East Asian "miracle": during 1965-90 the working-age population of East Asia grew nearly ten times faster than the dependent population. Age structure is not the only influence on economic growth, but it certainly emerges as one of the most potent influences.

\footnotetext{
${ }^{1}$ Hanushek (1992); Knodel and Wongsith (1991); Knodel, Havanon, and Sittitrai (1990); and Rosenzweig (1990) all find some microeconomic evidence for a negative effect of family size on school enrollment rates or educational attainment.
} 
Changes in the age distribution of the population can have important economic effects. These effects reflect the influence of changes in the number of working-age individuals per capita (which we term the "accounting effect") and of shifts in behavior, for example, increased savings and greater investment in schooling per child as both desired and completed fertility fall. However, these effects are not automatic consequences of fertility decline. They depend on many policies, institutions, and conditions that determine an economy's capacity to equip its people with human and physical capital and to absorb them into productive employment.

These recent findings indicate that when it comes to economic growth and development, population matters. This conclusion gains significance in light of existing knowledge regarding policy interventions aimed at accelerating the pace of fertility decline, such as investments in child survival; in basic and secondary education, especially for girls; in family planning and reproductive health; and in improved labor market opportunities for women. Because the need for improved access to schooling and health care, as well as unmet needs for family planning supplies and services, are concentrated among the poor and those living in rural areas, social spending on these initiatives can improve not just income per capita, but also social equity.

The recent studies of the effects of population change on economic growth have two key features in common with another study that was published more than 40 years ago: Coale and Hoover's seminal book, Population Growth and Economic Development in Low-Income Countries (1958). All these works highlight and exploit the fundamental insight that reducing the current rate of population growth does not lead to a corresponding reduction in the current rate of labor force growth. In addition, they adopt a view that links between population and income proceed in one direction, from the former to the latter. 
However, these studies also share some potentially significant limitations. First, the imposition of a structure in which causality runs only from population growth to income growth is at odds with well-established microeconomic theory and a large body of supporting empirical evidence, which suggest that income levels influence the growth and structure of population. For example, people with high incomes naturally tend to place a high implicit value on their time. Given that child rearing is time intensive, it is not surprising that they also tend to have fewer children. This suggests that income growth tends to promote fertility decline. ${ }^{2}$

Reverse causality potentially undermines the accuracy of recent estimates of the effects of population change on economic growth because, as noted, those estimates presume a unidirectional causal framework. It also implies that policy implications based on those estimates may be seriously misguided. ${ }^{3}$ This paper applies a combination of economic reasoning and appropriate statistical methods to address this issue. We find strong evidence that population change affects income growth and that changes in income affect population growth, mainly through their effect on fertility. Our results confirm the importance of rapid and pronounced demographic change in East Asia for the region's economic success. They also suggest that the decline in fertility rates in the region was itself spurred by rapid economic growth. By contrast, South Asia's demographic transition was impeded by relatively stagnant and low income, which in turn slowed the decline of fertility.

Second, attention to population age structure is the key innovation in both the landmark study by Coale and Hoover and the recent literature. However, population growth and changes in age structure are only two of several plausible demographic influences on economic growth.

\footnotetext{
${ }^{2}$ Cheng and Nwachukwu (1997), in an effort to find a causal link from education to fertility in Taiwan, using aggregate data, instead find evidence that the causality runs the other way, from fertility to education.

${ }^{3}$ Bloom and Williamson (1998) make some attempt to address this matter, but when they do this, their estimates become very imprecise, making it difficult to draw decisive conclusions.
} 
Indeed, an important feature of the modern literature on the effects of demography on economic growth is the introduction of a broader definition of demography than simply the population growth rate (Barlow 1994; Bloom and Freeman 1988; Bloom and Sachs 1998; Bloom and Williamson 1998; Brander and Dowrick 1994; Coale 1986; Kelley and Schmidt 1995). In this paper we also consider several demographic variables in addition to age structure that may have an impact on income per capita: life expectancy and population density.

A robust finding from the recent economic development literature concerns the positive effect of good health status, as measured by life expectancy, on economic growth. Presumably, this finding reflects the greater incentives long-lived people have to save for old age (Mason 1998), increased returns to investments in human capital associated with having longer horizons over which to recoup those returns (Meltzer 1995), higher productivity, and lower rates of absenteeism.

Another potential influence on the pace of economic growth is population density. If natural resources, such as agricultural land, are fixed, increases in population density are likely to depress income per capita (see, for example, Ehrlich 1968 and Malthus 1798). By contrast, opportunities for specialization and scale economies can cause increased population density to promote higher income per capita (see, for example, Boserup 1981, Kuznets 1967, and Simon 1981). Following Bloom and Sachs (1998) and Gallup and Sachs (1998), who argue that coastal regions can enjoy greater benefits of specialization through trade, we separate population density in coastal regions from population density in inland regions.

The main objective of this paper is to examine the linkages between population change and economic growth within a framework that permits bi-directional causality. We begin, however, by presenting a simple descriptive analysis of the growth of income per capita in Asia 
and its subregions. The analysis shows that Asia's record of economic growth is associated with changes in three key factors: (1) the share of population in the prime working ages, (2) the productivity of labor in all sectors of the economy, and (3) the allocation of labor to the lowproductivity agriculture sector and the high-productivity industry and service sectors. We argue that all three factors have potentially strong linkages to various aspects of demographic change, especially changes in the age structure and rural-to-urban migration.

Next we examine the effect of demographic variables on the pace of economic growth, taking into account other influences on growth that are standard in the economics literature. We do this using statistical tools that account for the possibility of a feedback effect of income growth on the demographic variables. These tools permit us, in principle, to decompose the correlation between demographic change and income growth into two parts, one that reflects the causal impact of demographic change on income growth and another that reflects the reverse effect of income growth on demographic change.

Our examination is based on data for 70 countries from all regions of the world (all those for which the requisite data are available) and covers the period 1965-90. We examine data for the entire period, as well as within the five five-year intervals it spans. Our results indicate that sizable portions of both East Asia's economic success and South Asia's economic failure are attributable to the influence of demographics, namely, differences in health status, dependency burdens, and the spatial distribution and concentration of people. We also find strong evidence of a negative effect of income on fertility rates, together with a sharp downward trend in fertility between 1965 and 1990. Finally, we show that life expectancy increased substantially during this time, apparently independent of changes in average country income, notwithstanding the fact that rich countries have higher life expectancies than poor countries. 
In the first section we present and analyze key facts about the growth and structure of Asia's population since 1970 and its economic performance. We then examine the influence of different aspects of population change on the growth of income per capita in Asia and its subregions, emphasizing the contributions of population change that are independent of other influences on economic growth and any confounding feedback effects from income to population. This is followed by a look at the effects of income on the two most important components of population change: fertility and mortality. Here too we seek to isolate the effects of income from those associated with either other influences on population or feedback effects. We conclude by offering some thoughts on the implications of our findings for population policy and for the prospects for economic growth and development elsewhere in Asia and the world.

\section{Sources of Income Growth in Asia}

We begin our examination by setting forth some basic facts that describe the magnitude and underlying components of income growth in Asia in recent decades. We do this using a simple growth accounting framework that highlights possible demographic influences to analyze these facts. ${ }^{4}$

Table 1 summarizes the structure of Asian economies during 1970-90. For comparison purposes we also present equivalent information for Latin America and Sub-Saharan Africa, although the main focus of discussion here is Asia. Clearly, Asia registered impressive gains during this period as measured in terms of the growth of output per worker in all sectors. At the

\footnotetext{
${ }^{4}$ See Bloom and Williamson $(1997,1998)$ for the results of an alternative decomposition analysis that focuses on hours worked per worker, labor force participation by the working-age population, and the working-age share of the total population. However, those analyses do not examine productivity levels within sectors or the allocation of labor among sectors, which are components of economic performance that are connected to labor migration and population age structure (insofar as there are changes in savings rates over the life cycle that ultimately affect capital-to-labor ratios and productivity levels in different economic sectors.)
} 
same time, it shifted from being predominantly an agrarian region to one with rapidly expanding industrial and service sectors. South Asia and Southeast Asia are still primarily agricultural, although the signs of the start of their transformation into industrial and service-based economies are apparent. The industrial sector is by far the most productive in terms of output per worker, which is likely to be due to its higher levels of capital per worker.

Labor productivity increased sharply in Asia during 1970-90, substantially more than in Latin America and in Sub-Saharan Africa. However, the differences across regions of Asia are significant: while labor productivity increased substantially in all major economic sectors in East and Southeast Asia, in South Asia labor productivity increased only slightly in each sector during the period.

Table 2 reports labor force participation rates and measures of age structure. From 1970 to 1990 the labor force participation rate increased only slightly throughout Asia. The ratio of the working-age population to the total population also increased as a result of the region's demographic transition. However, in East Asia, where the decline in fertility rates began earlier and was far more rapid, the ratio rose to significantly higher levels than in Southeast and South Asia. Both these changes stimulated the growth rate of per capita income, because they raised the ratio of economically active people to dependents.

Table 3 summarizes average growth rates for the key processes that influence economic growth. While population growth was rapid across Asia as a whole, the growth rate of the working-age population (age 15 to 64) was even more rapid than that of population as a whole. In addition, the labor force increased at a more rapid rate than the working-age population, that is, a higher share of people of working age participated in the formal labor market in 1990 than in 1970. At the same time labor productivity increased across all sectors. All these factors 
contributed to Asian growth from 1970 to 1990, though to varying degrees. However, favorable demographic changes do not automatically produce income improvements. Similar increases in the participation rate and decreases in the dependency ratio did not lead to sharp per capita income growth in Latin America, where disinvestment and highly protectionist policies actually caused a decline in labor productivity.

To understand the nature of economic growth in Asia, we apply a simple shift-share accounting framework. This framework, which is fundamentally a descriptive tool, builds on two related accounting identities. The first identity expresses output per capita as equal to output per worker multiplied by the participation rate of those of working age times the ratio of those of working age to total population. ${ }^{5}$ This allows us to decompose the growth in output per capita into productivity gains in output per worker and the effects of changing participation rates and age structure. The second identity expresses output per worker as equal to productivity per worker in each sector weighted by each sector's employment share. ${ }^{6}$ This identity allows us to

\footnotetext{
${ }^{5}$ More formally, we specify the following identity for output per worker in country $i$ at time $t$.

$$
\left(\frac{Y_{i t}}{L_{i t}}\right)=s_{i t}^{A}\left(\frac{Y_{i t}^{A}}{L_{i t}^{A}}\right)+s_{i t}^{I}\left(\frac{Y_{i t}^{I}}{L_{i t}^{I}}\right)+s_{i t}^{S}\left(\frac{Y_{i t}^{S}}{L_{i t}^{S}}\right)
$$

This equation is a simple employment-weighted average of labor productivity across three broad economic sectors: agriculture, $A$, industry, $I$, and services, $S$. The $s$ 's refer to the shares of the labor force that work in each sector, while the values in parentheses equal output per worker for each of the three sectors respectively. We use the term productivity to refer to output $(\mathrm{Y})$ per worker $(\mathrm{L})$, which is different from total factor productivity, an index of technological progress used in most production function analyses.

${ }^{6}$ This identity, which also holds for in country $i$ at time $t$, is written as follows.
}

$$
\left(\frac{Y_{i t}}{P_{i t}^{T}}\right)=\left(\frac{Y_{i t}}{L_{i t}}\right) \cdot\left(\frac{L_{i t}}{P_{i t}^{W A}}\right) \cdot\left(\frac{P_{i t}^{W A}}{P_{i t}^{T}}\right)
$$

where output per capita (Y/P) is expressed as the product of output per worker (Y/L), the labor force participation rate $\left(\mathrm{L} / \mathrm{P}^{\mathrm{WA}}\right)$, and the share of the working age population $\left(\mathrm{P}^{\mathrm{WA}} / \mathrm{P}^{\mathrm{T}}\right)$. 
decompose overall productivity growth (that is, the growth in output per worker) into productivity growth within each sector and the reallocation of workers across sectors.

By definition, the relationships expressed by these identities hold at all points in time. This allows us to calculate levels of output per capita and productivity per worker that would have occurred if certain factors had not changed. For example, we can estimate economywide productivity per worker in 1990 under the assumption that productivity per worker in each sector had not changed from its levels in 1970. The difference between actual productivity per worker in 1990 and this hypothetical level of productivity per worker can therefore be interpreted as an estimate of the effect on overall productivity per worker of changes in the movement of workers between sectors with differing levels of productivity. This basic approach can be applied in a variety of ways to estimate the contributions to changes in income per capita and productivity per worker of various factors, including sector-by-sector productivity levels, labor force participation rates, age structure, and allocation of labor across sectors.

Tables $4 \mathrm{a}$ and $4 \mathrm{~b}$ summarize these contributions in both relative and absolute terms. Economists attribute much of East and Southeast Asia's success to rapid increases in productivity, and indeed, we estimate productivity increases of 3.2 percent a year in East Asia and 2.3 percent a year in Southeast Asia. By contrast, productivity growth contributed only around 0.5 percent a year to total growth of output per capita in South Asia, and this was due mostly to productivity increases in the agriculture sector, where most of the labor force was concentrated. Changes in labor, including reallocation of labor between sectors, changes in participation rates, and changes in age structure, contributed more than twice as much to growth in South Asia, accounting for almost 70 percent of the change in output per capita during the period under review. The corresponding changes were, however, larger in absolute terms in East 
Asia, even though they accounted for only 40 percent of overall income growth. Reallocations of labor from the low-productivity agriculture sector to the higher-productivity service and industrial sectors alone account for about a fifth of the growth in per capita gross domestic product (GDP) in each of the three regions. This shift closely mirrors the rapid rates of urbanization in Asia and highlights the importance of the link between the urban and rural sectors represented by migration. However, reallocation of labor into the industrial sector also requires substantial investment if capital per worker and output per worker are not to be diluted. The changing age structure effects also contributed more than 10 percent of the growth in each region. In East Asia, where the demographic transition is already well under way, it accounted for 0.7 percentage points of growth. Southeast and South Asia have yet to feel demographic transition impacts of this magnitude.

Thus during 1970-90, per capita income growth in Asia can be accounted for by three main factors. First, productivity grew in all sectors. Second, labor was reallocated from lowproductivity agriculture to the high-productivity industrial and service sectors, mainly through migration from rural to urban areas. Third, the proportion of working-age people increased. The labor force participation rate of those of working age in Asia increased only modestly.

If the relationship between demographic factors and economic growth were purely a matter of accounting, we could end our analysis here, having demonstrated a substantial demographic contribution to economic growth rates. We have conducted our shift share decomposition of effects on the implicit assumption that changes in each component are independent of each other. However, Asia's experience suggests that population change and productivity growth are not independent. For example, during 1970-90 East Asia had both the fastest-growing productivity per worker and the most favorable changes in demographic 
structure. By contrast, both economic growth and fertility decline were comparatively slow in South Asia. Note also that the age structure effect in Latin America and the Caribbean was actually similar in magnitude to that in East Asia during the same period, but overall economic performance was much worse, indicating that any link between demography and productivity is not automatic.

Productivity, particularly in manual occupations, may depend on workers' health. Productivity growth is also linked to investment rates, both in physical and human capital, and demographic factors may have an impact on these through their effect on savings. Increasing life expectancy and the need for pensions in East Asia may have set off its savings boom, while its low fertility rate may have contributed to high education rates. Thus the productivity gains that we measure in the shift share analysis are likely not independent of demographic factors.

Similarly, economic success may have important consequences for demography. Health and life expectancy may rise with income as people gain greater food security and access to health care, both publicly and privately. In addition, evidence suggests that fertility rates fall with increased income, thereby lowering the dependency ratio and perhaps allowing an increase in labor force participation rates. Thus at least some of the demographic change we observe may be the result of economic growth rather than its cause.

We postulate that for developing countries a strong positive feedback mechanism exists between demographic change and economic growth. Economic growth tends to increase life expectancy and reduce fertility, leading to further economic growth through lower dependency ratios and increasing savings rates. This can lead to a virtuous cycle of cumulative causation when growth becomes self perpetuating. To understand this process we need to understand the 
causal mechanisms linking demographic change and productivity growth and not simply treat each as independent processes.

Pure accounting frameworks are not well suited for studying causal links such as those that might involve demographic change and economic growth. The decomposition analyses presented in this section merely provide an indication of the relative importance of various influences on the growth of per capita income. As such, they provide some important benchmarks for the further analyses reported in the following sections.

\section{The Contribution of Demographic Factors to Asia's Economic Growth}

We use cross-country regression analysis to estimate the contribution of demographic factors to economic growth in Asia. The appendix presents the theoretical basis for the multiple regression analyses we perform. Here we rely on a more readily comprehensible description of our framework.

In recent years development economists have relied heavily on cross-country data to study the process and determinants of economic growth. Two key assumptions lie at the core of many of these studies. First, there is a ceiling on the level of income per worker that a country can attain. This ceiling, which is usually denoted as the country's steady-state level of income, depends on the country's characteristics, such as the extent of its natural resource base, the level of education of its population, the quality of its institutions, the features of its physical geography, and the nature of its economic policies. Because these characteristics vary across countries, so too will the levels of income they can attain.

Second, development economists assume that the difference between a country's potential income and actual income is reduced every time period by a constant fraction. Thus 
countries are continually tending to approach their ceiling levels of income, though at any point in time, their actual incomes will differ from the attainable ceiling. ${ }^{7}$

Figure 1 depicts this model for a representative country. It shows the ceiling level of income, which is stable over time. It also shows the initial level of log income per worker at time 0, which lies below the ceiling level. Finally, it shows the trajectory of income, which rises over time, but at a decreasing rate, indicating that actual income continually gets closer to the ceiling. It should be noted that the slope of the income trajectory, that is, the change in income per unit time, is the growth rate of income.

This model of economic growth has two powerful implications. First, it implies that the poorer a country is with respect to its steady state, the faster it is likely to grow. This is sometimes referred to as the income catch-up phenomenon. Second, the higher a country's ceiling level of income, the faster its expected rate of growth for a given level of initial income. This has been dubbed "conditional convergence".

Although this model is developed in terms of income per worker, it is generally tested using data on income per capita, development economists' standard measure of economic performance. Because the model is estimated using growth rates, as opposed to levels, of income, distinguishing between income per person of working age and income per capita makes no difference in stable populations (for which the growth rate of the overall population is equal to that of the working-age population). However, the assumption of demographic stability is patently violated by the data for most countries, including Asian countries at various stages of their demographic transition. Thus, following Bloom and Williamson (1998), we invoke the

\footnotetext{
${ }^{7}$ It should be noted that countries can have income levels above the ceiling. For example, adopting bad economic policies or a fall in the world price of a country's major export can cause the steady state level of income to fall so that countries are temporarily above the new steady state and experience negative economic growth. In this sense, the "ceiling" is not a strict upper limit on income. Rather, it defines the direction in which income levels will tend to
} 
relationship between income per capita and income per worker, that is, income per capita equals income per worker multiplied by the ratio of workers to the population as a whole. Allowing also for the possibility that population growth and labor force growth may affect income in ways other than through pure accounting yields the multiple regression equation we actually rely upon to estimate the determinants of the growth of income per capita:

$$
g_{y}=\alpha_{0}+\alpha_{1} y+\alpha_{2} \log (L / P)+\alpha_{3} g_{L}+\alpha_{4} g_{P}+\alpha_{5} X+\varepsilon
$$

where $\mathrm{g}_{\mathrm{y}}$ refers to the growth rate of income per capita, $\mathrm{y}$ is the natural logarithm of the initial level of income per capita, $\log (\mathrm{L} / \mathrm{P})$ is the natural logarithm of the number of workers per capita, and $\mathrm{g}_{\mathrm{L}}$ and $\mathrm{g}_{\mathrm{P}}$ are the growth rates of the working age and the overall populations respectively, over the sample period. $\mathrm{X}$ is a vector of factors that may influence the ceiling level of income, and $\varepsilon$ is a random error.

According to this equation, the growth of per capita income depends on the levels of income per capita (negatively) and workers per capita (positively) at the start of the sample period, the growth rates of the overall population (negatively) and the working-age population (positively), and the factors that determine the ceiling level of income (positively for any factor that raises the ceiling). For reasons discussed earlier, we include, among the latter set of factors life expectancy and population density, both measured at the start of the sample period. Population density actually refers to the density of the working age population, which is arguably more relevant to economic growth than the density of total population. We enter separate density variables for coastal and inland areas, because the effects of density may depend on access to world trade. These variables are based on data contained in the Geographic Information System, with inland areas defined as those more than 100 kilometers from the coast or a move. 
navigable river that leads to the sea (see Gallup, Sachs, and Mellinger 1998). Our specification deliberately omits savings and investment rates as explanatory variables, because they may reflect an uncertain amount of demographic influence, and because they are likely determined jointly with the growth of income per capita.

\section{Cross-Country Results}

We report two sets of multiple regression equations for the determinants of economic growth. First, we estimate the determinants of growth in a standard cross-country framework with data for 70 Asian and non-Asian countries from 1965-90. We use instrumental variables to correct for possible reverse causality between the growth rates of the total and working-age populations and economic growth. We treat all variables measured at the start of the sample period, before the growth has occurred, as immune from the problem of reverse causality.

Second, we repeat the exercise using panel data for the five consecutive five-year periods spanned by the years 1965-90. That is, we seek to explain each five-year growth experience with data on conditions at the beginning of the five-year period and demographic change during the period, again using an instrumental variables approach to deal with possible reverse causation. This allows the level of initial income and the factors that influence the ceiling level of income (and therefore the rate of income growth) to vary over time. We also allow for average differences in the rate of income growth between the five-year periods, which could reflect differences in worldwide levels and rates of change of technical knowledge.

Table 5 reports our cross-country estimates for 1965-90. Summary statistics for the data used in the cross-country regressions are reported in table 10 . Column (1) reports results for a specification that is representative of the economic growth literature. It includes initial income 
per capita, schooling, openness to international trade, institutional quality, and geographic factors such as whether or not a country is located in the tropics and whether it is landlocked (see for example, Barro 1991; Barro and Sala-i-Martin 1995; Gallup, Sachs, and Mellinger 1998). The coefficient of initial income per capita is significantly negative, consistent with the hypothesis of conditional convergence. The other variables are assumed to determine the steady-state level of income. Development economists have long argued that education is a prime determinant of long-run economic performance; we follow Barro and Sala-i-Martin (1995) who argue that secondary schooling appears to be the most important component of education. Sachs and Warner (1997) argue that the level of openness to trade is an important predictor of growth. They suggest that trade plays an important role in the growth process because it encourages market competition, improves the efficiency of resource allocation within the economy, combats monopolies, and acts as a vehicle for the importation of new technology. The quality of institutions, as captured by the Knack and Keefer (1995) index, is another possible determinant of economic growth, with institutional quality being positively correlated with growth.

Geographic variables also appear to play an important role. The percentage of a country's land area that is in the tropics has a significant negative effect on economic growth. Researchers have shown that tropical location affects various factors that can influence productivity. For example, the burden of several infectious diseases such as malaria and schistosomiasis is significantly higher in warm, humid climates. Furthermore, Gallup (1998) shows the existence of a strong link between climate and agricultural output. The cost of transportation, as determined by geography, is another important factor, as illustrated by the negative (and marginally significant) effect of being landlocked. 
While each of these variables plays an important role in the growth process, with the exception of life expectancy, the standard growth literature has generally placed little emphasis on the role of demographic variables in economic growth. Column (2) reports the results of a regression that includes a full set of demographic variables. These include the growth rates of the total population and of the working-age population and the natural logarithm of the initial ratio of the working-age population to the total population, as described in the appendix. We also add the log of life expectancy in 1965 and coastal and inland population densities as demographic variables that may directly affect steady-state income levels.

To correct for possible reverse causality involving the growth rates of the working-age and total population during $1965-90$, we instrument these variables with the growth rates of the working-age and total population during 1960-65 and the 1965 fertility and infant mortality rates. These instruments appear to be highly correlated with the population growth rates during 196590 and can be considered as predetermined in that they are measured no later than at the outset of the period of economic growth under study. The results of using these instrumental variables are shown in column 3.

In both columns (2) and (3), five of our six demographic variables are statistically significant and their inclusion in the specification significantly improves its explanatory power (raising the $\mathrm{R}^{2}$ from less than 0.6 to more than 0.8 ). These results confirm the importance of demographic factors in the growth process. One of the most robust results is the importance of life expectancy in predicting economic growth. Life expectancy can affect economic growth through several mechanisms. For example, as people live longer, they can be expected to save more to ensure that they have enough assets put aside for a longer period of old age (Lee, Mason, and Miller 1998). In addition, changes in the age distribution can affect aggregate savings due to 
variations in savings behavior at different stages of the life-cycle (see Higgins 1998; Higgins and Williamson 1997; Kelley and Schmidt 1996; Modigliani 1986).

Life expectancy also serves as a proxy for the health status of the population as a whole, because declines in the mortality rate are related to declines in morbidity. A growing literature shows that a healthier work force is more productive (see, for example, Bloom and others 1998; Strauss and Thomas 1995). These effects are particularly strong in developing countries, where a greater proportion of the work force is involved in manual labor, which is heavily dependent on physical well-being.

Population growth as a whole has a strong negative impact on economic growth, while growth of the working-age population has a strong positive impact. These results persist, and remain statistically significant, even when we use instrumental variables to control for reverse causation.

We also find that population density along the coast has a positive effect on economic growth, while population density inland has a negative effect. The divergence may be explained by noting that coastal regions are better able to integrate into the world economy and can capture the fruits of specialization and scale economies through international trade. Inland regions, particularly landlocked countries, face higher transport costs in reaching world markets and so have much tighter resource constraints. In countries where the population is predominantly inland, as in landlocked countries, high population density may put pressure on agricultural production and depress income levels. Burundi and Rwanda are two examples of landlocked countries with high population densities and low incomes. However, if the population has access to the sea and cheap sea trade routes, higher population density may allow greater specialization and exploitation of scale economies. Hong Kong and Singapore are examples of high population 
density areas with easy access to the sea and with high incomes, due in large part to their reliance on external trade. By contrast, Bangladesh is the most densely populated country in the world with three major rivers that run through it to the Bay of Bengal, but its economic performance is extremely poor.

Column (4) reports the results of imposing the restrictions implied by our growth accounting framework. Under these restrictions we can replace the income per capita and workers per capita terms with a single income per worker term. In addition, only the difference in the growth rates of the working-age and total population should matter. An F-test of these two restrictions gives a value of $\mathrm{F}(2)=1.47$ and they cannot be rejected. This implies that we find no significant effect of balanced population growth (i.e., when the labor force and total population are growing at the same rate). However, the further restriction that the coefficient on the difference between the working-age and total population growth is equal to 1 is rejected by a test with $t=2.56$. This suggests that reducing the birth rate and the dependency ratio has a significantly larger effect on growth rates than the pure accounting restrictions would suggest.

Columns (5) and (6) report the results of specifications that include dummy variables for Africa, Latin America, and the subregions of Asia: East Asia, Southeast Asia, and South Asia. When these dummies are added to the base specification in column (5), we find that while this specification is quite successful in explaining growth in both Africa and Latin America, both East and Southeast Asia have significant dummies. If we define the Asian economic miracle as that part of its growth rate that standard growth determinants cannot explain, we obtain figures for "miracle" growth of around 3.5 percent a year for East Asia and 1.5 percent a year for Southeast Asia. Growth regressions such as these often find a negative coefficient on the Africa 
dummy, but the inclusion of the geography variables helps to explain Africa's poor performance and eliminate this unexplained residual (see Bloom and Sachs 1998).

Adding demographic variables as in column (6) explains almost all of East Asia's "miracle" growth. Once demographic variables are included, the East Asian miracle is less than 1 percent growth per year, while the miracle in Southeast Asia is less than 0.5 percent growth per year, and in neither case are these figures statistically significant. The only significant outlier in column (6) is South Asia, which underperformed the rest of the world's economies by about 1.3 percent in annual growth during the period given its initial conditions and its demographic and other characteristics. The mystery in Asia may not be why East Asia did so well, but rather why South Asia has performed so poorly.

\section{Panel Data Results}

Table 6 presents panel data results to test the robustness of our cross-country results. We are essentially running five cross-section regressions, one for each five-year period between 1965 and 1990, and assuming common coefficients across time periods. As explanatory variables we use initial conditions from the start of each five-year period and population growth rates over the five-year period. We try to use the same set of explanatory variables as in table 5 , but include a set of time dummies to capture worldwide shocks to growth in each five-year period relative to the base period, $1985-90 .^{8}$

Column (1) reports the base specification used in the first set of regressions. The results are similar to those in table 5. Adding demographic variables in column (2) once again shows the

\footnotetext{
${ }^{8}$ We do not introduce country fixed effects, because the necessary presence of the initial income level would then result in inconsistent (biased) coefficient estimates. While this problem can be overcome (see Islam 1995), the techniques required involve instrumenting all the explanatory variables, with a consequent large loss of precision in the estimates.
} 
importance of each of these factors, as most enter significantly into the regression equation. Unfortunately, data on coastal versus inland population density is not available on a time series basis, precluding its use in the panel study. Instead we use the overall density of the working-age population, which never turns out to be statistically significant in our regressions, and may be a poor proxy for the disaggregated densities, which have opposite signs in the regressions reported in table $5 .{ }^{9}$

Column (4) in table 6 again imposes the accounting restrictions implied by our theoretical framework. The two equality restrictions are once more accepted, with an F-statistic of $\mathrm{F}(2,375)$ $=1.031$. In this case we also accept the restriction that the coefficient on the difference between the growth rates of the working-age population and total population is unity ( $t$-statistic 1.17). The panel data results indicate that the age structure effects are close to those predicted by a simple accounting framework, and that the behavioral effects of demography are coming entirely from the effect of increased life expectancy on economic growth.

The difference in results between the 1965-90 cross-section and the panel data analyses, which persist even with identical specifications, deserves comment, because we suspect that it marks the existence of feedback effects from income to demography and places some bounds on the time frame within which they occur. Over a twenty-five year period, an increase in the differential population growth rate caused, say, by the introduction of some new contraceptive technology, can increase income levels, leading to further reductions in fertility and increases in life expectancy that have appreciable effects on the dependency burden and provide a further boost to economic growth. Twenty-five years is long enough for demographically-induced income growth to accelerate the process of demographic transition and the related process of

\footnotetext{
${ }^{9}$ Kelley and Schmidt (1998) have re-estimated these regressions over a different sample of observations and do find significant effects for density and the initial working age ratio.
} 
economic growth. Five years may not be long enough for these causal mechanisms to work themselves through.

Including the dummy variables with the base specification in column (5) again shows East Asia to be a significant outlier, with a growth rate about 2.7 percent a year above that explained by the regression. However, once we add our (instrumental) demographic variables about half this "miracle" growth, or some 1.4 percentage points, disappears. Indeed, when we include demographic variables, once again the East Asian dummy is not statistically significant, suggesting there was nothing "miraculous" about East Asia's income growth. In addition, when comparing columns (4) and (5) the negative African dummy, which represents growth rates 2.2 percent a year lower than Africa's objective conditions would suggest, disappears once we add demographic variables. These results show that demographic factors have played a large role in both East Asia's economic miracle and Sub-Saharan Africa's economic debacle.

This section has approached the issue of feedback effects indirectly by comparing the long- and short-term effects of demographic factors on the pace of economic growth. However, our interpretation is, nevertheless, highly tentative, especially given the similarity of the ordinary least squares and the instrumental variables estimates. ${ }^{10}$ The next section provides some direct evidence concerning the effects of income on vital rates. That evidence leads us, unambiguously, to prefer this section's instrumental variables results because they are, in principle, robust to reverse causation.

\footnotetext{
${ }^{10}$ For example, Hausman specification tests do not permit us to reject the exogeneity of the population growth rates in our regressions.
} 


\section{The Effects of Income on Life Expectancy and Fertility}

The preceding section examined the effects of demographic factors on economic growth. In this section we turn to the reverse matter of the effects of economic growth on demographics. We focus on life expectancy and fertility rates, partly to take advantage of the extensive literature on their determinants at both the household and national levels.

In the case of life expectancy, Fogel (1994) argues that declines in European mortality during the industrial revolution followed economic growth. Preston $(1975,1980)$ attributes most of the decline in death rates observed around the world between 1930 and 1970 to factors such as advances in health care technology, and only a small portion to economic growth. Working with data from 1960 for developing countries, Pritchett and Summers (1996) find a significant effect of income and education in reducing infant mortality and argue that the relationship is causal, but they find no significant effect of income on life expectancy. It may seem plausible, even obvious, that economic growth leads to improved health and longevity, but the evidence is far from conclusive.

With respect to fertility, Becker and Barro (1988) argue that rising income leads to a higher opportunity cost of time and a reduction in the desired number of children. Caldwell (1982) argues that children in agricultural societies provide services, such as tending livestock, gathering fuelwood, and fetching water, thereby raising their parents' standard of living, and that the process of industrialization and economic development results in children becoming a net economic burden on their parents, especially as mobility increases and schooling becomes compulsory. This leaves only altruism as a motive for child bearing, and consequently family size falls. Wang and Jamison (1997) find effects of both income level and education rates, particularly female education rates, on fertility. There is also an ongoing debate about the relative 
importance of family planning programs versus economic development as determinants of fertility. Gertler and Molyneaux (1994), Schultz (1994), and Pritchett (1994) show that desired fertility, as determined by economic forces such as education levels and wage rates for women, play a significant role in determining completed fertility, while family planning activity seems less important. Even though Bongaarts (1994) contests some key components of this collection of studies, they do suggest that fertility decline is at least partly influenced by economic growth, though the mechanism relating economic growth and fertility decisions may, in part, operate indirectly via other variables.

We foresee continuing discussion on the nature and strength of these linkages. Our immediate concern, however, is not to resolve, or even contribute to, these longstanding debates. Rather, we simply wish to use country-level data to examine the existence of any feedback from economic growth to fertility and life expectancy, particularly in the context of Asia, without getting into issues related to its precise structure.

We begin our analysis with life expectancy. Investigators have shown that many factors besides income affect health and life expectancy. Education levels, particularly female education levels; number of physicians per capita; health expenditures per capita; and access to clean water and sanitation are but a few that explain cross-country differences in life expectancy (World Bank 1993). If we include these variables in a study of the proximate determinants of life expectancy, the estimated effect of the income level is the effect holding all these other factors constant. Note that all these proximate determinants of life expectancy are themselves, to some extent, dependent on the income level and move with it. To estimate the total effect of changes in the income level on life expectancy we follow Pritchett and Summers (1996) and exclude factors 
that affect life expectancy, but may themselves be determined by the income level. This allows us to estimate both the direct and indirect effects of income per capita on life expectancy.

Our earlier admonitions about reverse causality apply with equal force to estimating the effect of income levels on demographics. We address this issue in a similar manner as before, using the well-established instrumental variables regression approach to purge actual income of the component that is due to reverse causality. Ultimately, the validity of this procedure depends on having a set of instrumental variables that are good predictors of income, but that are not directly linked to life expectancy. For this purpose we use a measure of the openness of the economy during the previous five years, the black market premium on the currency exchange rate, the proportion of the country's land mass within 100 kilometers of the coast, a dichotomous indicator for landlocked countries, and the distance between the capital city and major world markets. These policy and geographic variables are correlated with income levels, but have no obvious direct connections to health status. ${ }^{11}$

The effect of a change in income on life expectancy is likely to be felt only in the long term, because health status is related to many events and conditions experienced over the life cycles of each member of the population, particularly when they were young, as well as to current income. A complex population selectivity process is also involved, because the most frail members of the population will tend to die at earlier ages, leaving increasingly high concentrations of physically robust individuals in the population (see Manton and Stallard 1984). The short-run effect of changes in income on changes in life expectancy may mislead us about the long-run effect. To capture the long-run effect, we focus on estimating the relationship

\footnotetext{
${ }^{11}$ We avoid using as instruments geographic variables such as latitude or tropical location that may be directly related to health status though climate. Also, we do not follow Pritchett and Summers (1996), who include the ratio of investment to income as an instrument. Our reservation is that the investment rate may be responding to demographic factors, either through the attractiveness of investment when workers are healthier, or though longer
} 
between life expectancy and income level, rather than the changes in each. We adopt a panel study approach, including a set of time period indicators, to capture the effects of health advances and increased access to those advances over the 25 years (1965-90) under consideration. We also include indicator variables for each country (referred to as country fixed effects) to capture the effect of country-specific conditions, such as climate and weather patterns, on life expectancy.

Table 7 reports the results of this analysis. ${ }^{12}$ We use GDP per worker as the explanatory variable, because our theory suggests that GDP per capita is affected by the numbers of nonworking young and old in the population and is more likely to reflect the consequences of changes in life expectancy and fertility. As in the previous section, ordinary least squares estimates are reported as a benchmark for the other results (column (1). Our cross-country instrumental variables estimates, reported in column (2), suggest that a 10 percent rise in income per worker increases life expectancy by 1.9 percent. As the standard error of this parameter estimate is small, the effect is significantly different from zero at all conventional test levels. The estimates also indicate that life expectancy rose an average of 5 percent from 1965 to 1990 for countries in the sample, above and beyond the increase due to income growth during the period.

Adding regional indicator variables in column (3) suggests that life expectancy is some 9 percent higher in East Asia and 6 percent higher in Southeast Asia than we would expect given their income levels, while Africa has a life expectancy around 9 percent lower than its income levels would suggest.

\footnotetext{
life expectancy generating savings for retirement.

${ }^{12}$ Variables are expressed in natural logarithms so that the coefficients can be interpreted as measures of the percentage change in life expectancy associated with a unit change in each explanatory variable. In the case of income per worker, a unit change also corresponds to a 1 percent increase, because this variable is expressed in units of natural logarithms. All the other variables are dichotomous, which means that they take on the value of one if a particular observation possesses the characteristic in question, and a value of zero otherwise. The coefficients for these variables can thus be interpreted as the percentage difference in life expectancy between observations with and
} 
The positive income coefficients in regressions (1) and (2) indicate that the relatively large income differences across countries in our sample are positively associated with differences in life expectancy. Introducing country fixed effects raises the subtly different question of whether changes in a country's income over time are associated with changes in that country's life expectancy. Here we find that the introduction of country fixed effects drives the income coefficient to zero and suggests that the roughly 15 percent increase in world life expectancy from 1965 to 1985 was entirely independent of income growth.

The fixed effects results are somewhat puzzling insofar as they indicate that health improvements have not been relatively larger among those countries with higher income growth. Some countries, such as China, Cuba, and Sri Lanka, have managed to achieve impressive levels of life expectancy at low levels of income. For other countries, perhaps the effects of income changes on health only reveal themselves over time frames that are longer than 25 years. ${ }^{13}$ Mortality rates, even of the old, may depend on nutrition levels and health care when young, so that health status is somewhat inertial with respect to income changes.

To study the effects of income on fertility we follow exactly the same approach as for life expectancy. Our estimates are reported in table 8. The instrumental variables regression in column (2) suggests that 10 percent higher income is associated with 4.9 percent lower fertility. East Asia and Latin America stand out when regional indicator variables are added to the equation. East Asian fertility is 40 percent lower than we would expect given its income, whereas Latin American fertility is 25 percent higher.

\footnotetext{
without the particular characteristic.

${ }^{13}$ Technically, our instruments may not fully capture time series movements in income levels, but this seems unlikely, given that we find similar results using ordinary least squares and that our instruments do produce significant results when we explain fertility changes.
} 
The estimates also reveal a sharp downward trend in fertility, independent of the effect of rising incomes. For example, fertility was roughly 22 percent lower in 1990 than in 1965, holding income levels constant. Presumably this trend reflects increased knowledge about, and availability of, contraceptives; changing attitudes toward family planning; higher levels of schooling and better job market opportunities, especially for women; and rising female influence on household decisions.

In a fixed effects framework the coefficient on income in column (5) indicates that a 10 percent rise in income produces a 2.2 percent fall in fertility. The standard error of the coefficient estimate with fixed effects is much higher, because of the need to estimate 107 coefficients corresponding to the country indicator variables, but the estimated coefficient is still statistically significant at the 5 percent significance level. These results suggest that the negative effect of income on fertility is quite robust. Not only do countries with higher income levels have lower fertility, countries that increase their income levels over time reduce their fertility levels, and these results hold when we use instrumental variables as controls to safeguard against picking up feedback effects from fertility to income. The fixed effects results also indicate a sharp worldwide reduction of fertility rates (30 percent), independent of rising incomes.

A comprehensive study of the proximate causes of health and fertility would include the explanatory variables we have examined, as well as many others. Our concern, however, is limited to establishing whether variations in income (due to sources other than health and fertility, respectively) have impacts on health and fertility. With respect to health, our main finding is that higher income is associated with better health across countries, though not within countries, over time. With respect to fertility, our main finding is that higher income leads to lower fertility across countries, and also for individual countries over time. The results suggest a 
strong feedback from economic growth to demographic change, certainly with respect to fertility.

The results also indicate that demographic characteristics in East Asia were particularly favorable for economic growth during 1965-90, with considerably higher levels of life expectancy than can be accounted for solely on the basis of income. The very sharp decline in fertility rates from 1965-1980 was also extremely important in this process.

\section{Discussion}

Cumulative Causality and Asia's Development

Perhaps the most striking feature of the global distribution of income is the remarkably wide gulf in income per capita between industrial and developing countries. For example, income per capita in the United States is roughly 50 times higher than that in Chad (after adjusting for differences in purchasing power). Within Asia, income levels in Japan are around 13 times those found in Bangladesh. It is difficult to explain such extreme gaps in terms of differences in the circumstances these countries face with respect to their geography and physical environment, their technological options, and their underlying tastes and preferences for different goods and services and other determinants of the quality of life. This difficulty has led to the generation of models of endogenous growth (see, for example, Lucas 1990; Romer 1993) that attempt to explain large income differences as the result of a self-sustaining growth process involving two-way linkages between income and capital (both physical and human).

The interaction between demographic change and economic growth means that we must view the growth process as a system with causality running both ways. This interaction can also support an endogenous growth process. Becker, Murphy, and Tamura (1990) and Ehrlich and Lui (1991) construct theoretical models in which the interaction between fertility rates, mortality 
rates, and economic growth can give rise to self-sustaining economic growth. However, once takeoff has been achieved, the sustained growth in these models is due to the assumption that there are no diminishing returns to capital (both physical and human), which is difficult to substantiate empirically.

Our central conclusion is that the interaction between demography and economic growth gives rise to the possibility of cumulative causation, but only for a limited period of time. Initial increases in life expectancy and reductions in fertility and in the youth dependency ratio can have a large impact on economic growth in developing countries. This growth in turn leads to further reductions in fertility rates, and perhaps to an increase in life expectancy. These demographic changes set up another round of economic growth, and so on. This process does, however, have a natural limit. Decreases in fertility rates lower the youth dependency rate in poor countries, but lead to the certainty of a smaller working-age population in the more distant future when elderly dependency ratios, that is, the ratio of retirees, whose ranks are further swelled by increases in life expectancy, to workers inevitably rise. The demographic transition gives a boost to economic growth for a period, but eventually its effects subside.

Poverty traps arise naturally in this view of the world. Poor health and high fertility keep income down, which in turn impedes the process of demographic transition and perpetuates the state of low income. Breaking free of this trap requires some external stimulus, either to income, health, or fertility. A sufficiently large stimulus can catalyze a self-sustaining process of rapid economic growth and demographic change, which eventually settles down when the economy achieves high income levels, high life expectancy, and low fertility. This idea is supported by the work of Quah (1997), which shows that the global distribution of income is dominated by two distinct groups of countries, the poor and the rich, with few countries in between. Many theories 
have been put forward to explain the bipolar nature of the country distribution of income per capita (or, more technically, the existence of multiple equilibria in income levels). These are reviewed by Azariadis (1996). However, identifying the mechanisms that actually matter is ultimately an empirical issue. In this connection, our evidence-based view is that the feedback relationships between demographic change and economic growth are strong enough to suggest that they play an important role in explaining income differences between nations.

An important implication of the systems approach we are advancing is that outcomes are determined by two factors: the external forces that tweak and trigger the system, and the linkages through which those stimuli are channeled. It follows that demographic change can be important for economic growth in two ways. First, changes in fertility and mortality caused, for example, by the public provision of family planning and reproductive health services, can have a direct effect on the age distribution, which in turn has a direct effect on income per capita. Alternatively, even if higher incomes were the best and only contraceptive, an initial boost in income could promote demographic change and further increases in income. The operation of a multiplier mechanism of this type can greatly magnify any initial increases in income and generate rapid, that is, endogenous, growth and a two-tier distribution of country income per capita. An important implication of this cumulative causation framework is that even relatively small stimuli can ultimately have a powerful effect on income if the linkages among population, capital, and income are sufficiently strong. Indeed, the nature and strength of the linkages determines whether the effect of a particular catalyst on, say, income, is ultimately multiplied or dampened. 


\section{Looking Forward}

We can use our analysis of the period 1965-90 to help predict what the future may hold for Asia. Table 9 reports levels and changes in several key demographic variables that our results suggest are linked to economic growth. The figures clearly show that the demographic "bonus" that East Asia has enjoyed is beginning to dissipate. The dependency ratio in East Asia fell from 0.78 in 1965 to 0.48 in 1995 . However, the differential between the growth rates of the workingage population and the total population slowed from 0.68 percent a year during $1965-90$ to just 0.18 percent a year during $1990-95$. We anticipate a further rise in the dependency ratio because of projected increases in longevity. The combination of these demographic changes and the change in East Asia's income levels (East Asia moved from being roughly at the world average in 1965 to twice the world average in 1995), strongly suggest a slowing of income growth.

The demographic characteristics of Southeast Asia today are remarkably similar to those of East Asia in 1965. Like East Asia, though less extreme, Southeast Asia is an outlier in our demographic regressions, column (3) in tables 7 and 8 . The life expectancy of its population is higher and its fertility lower than its income level would otherwise suggest. Its working-age population is now growing 0.59 percent a year faster than its total population, indicating the prospect of a rapid decline in the current dependency ratio of 0.68. Given Southeast Asia's low income levels, relatively high stocks of human capital, and past success at improving labor productivity, the demographic effects suggest that in the coming decades, Southeast Asia could well experience economic success on a par with that of East Asia.

The situation in South Asia is more difficult to judge. Both in terms of income and demography, it is clearly at an earlier stage of development than East or Southeast Asia. Its life expectancy has improved and its fertility has declined somewhat, and tables 7 and 8 suggest that 
its demographic characteristics are in line with its income level. Current trends suggest a substantial decline in its dependency ratio in coming years, but given the region's history of slow productivity growth, whether it will be able to capitalize on this opportunity is unclear. Even given its demographic characteristics, regression results in table 5 suggest that South Asia underperformed the rest of the world economy substantially during 1965-90. Thus South Asia appears to demonstrate that the demographic transition is a necessary—but not a sufficient— condition for rapid economic growth. ${ }^{14}$

\section{Conclusion}

This study establishes the existence of strong linkages between demographic change and economic growth. These linkages run in both directions and suggest that the determination of both demography and income is partly governed by a multiplier mechanism. Within this framework, policy-induced changes in demographic or economic variables can promote a virtuous cycle of cumulative causation in which economics and demographics interact in a mutually reinforcing way. Even small initial changes can lead to a growth spurt that will continue until fertility rates stabilize at a low level. The same mechanism can also create the poverty traps that seem to have regions like Africa and South Asia in its grip. ${ }^{15}$

The analysis presented in this paper shows that demographic variables have played a large role in East Asia's economic success. Increases in life expectancy have had a large effect on incomes in East Asia. A rapid decline in fertility, induced partly by the region's economic

\footnotetext{
${ }^{14}$ This point about the demographic transition establishing favorable conditions for, but not guaranteeing, rapid economic growth is further illustrated by the financial and economic crisis that began in East and Southeast Asia in mid-1997. Although the immediate cause of the crisis was a massive outflow of foreign capital from a region that was heavily dependent on short-term debt, weaknesses inherent in domestic financial systems and the broader system of international finance undeniably contributed to the collapse (see Furman and Stiglitz 1998; Radelet and Sachs 1998), favorable demographics notwithstanding.
} 
success, led to a substantial reduction in the youth dependency ratio, thereby helping to boost growth rates of income per capita. East Asia appears to have had exceptionally favorable demographic characteristics in the form of high life expectancy and low fertility, despite its initially low income level. Strong feedback from income growth to demographic change, mainly in the form of fertility decline, helped complete the virtuous cycle of rising incomes and falling birth rates that we believe represents an extremely important part of the East Asian miracle.

Economic growth in East Asia will likely slow in the future, because of stabilization of fertility rates at their current low levels and increases in the dependency ratio as the population ages. By contrast, Southeast Asia appears primed for an acceleration of long-run economic growth driven by increasingly favorable demographics.

The presence of two-way causality between economic growth and the demographic transition means that care must be taken in interpreting correlations between demographic change and economic growth, even correlations that account for nondemographic influences on growth and non-income influences on demography. We must be careful to separate those components of both demographic change and economic growth that are determined within the system and those that are determined outside the system. We must also pay greater attention to the ways in which the interaction between economic growth and the demographic transition can give rise to cumulative causality and either a virtuous or a vicious cycle involving life expectancy, fertility, and income, perhaps along with other variables such as education and gender equity.

\footnotetext{
${ }^{15}$ There is some evidence that income growth does not lead to fertility decline until a threshold income level (about $\$ 1,500)$ is reached. This implies that a virtuous cycle of development will not operate below that level of income.
} 


\section{Appendix: Theoretical Framework}

This appendix provides a formal description of the theoretical framework that underlies our empirical specifications. The framework consists of a standard neoclassical model of economic growth, modified to account for life cycle variations in labor supply behavior (that is, not every member of a country's population is a worker).

Following standard practice, we begin by assuming a Cobb Douglas production function of the form

$$
Y=A K^{\alpha} L^{1-\alpha}
$$

where $\mathrm{Y}$ is total output, $K$ represents capital, $L$ represents labor, $A$ represents total factor productivity, and $\alpha$ is the elasticity of output with respect to capital.

We assume that the capital stock per worker $K / L$ is determined endogenously, and leave open the possibility that total factor productivity $A$ is also determined endogenously. In the neoclassical growth model of Cass and Koopmans (1965), total factor productivity is assumed to be exogenous, and the capital stock is determined by an intertemporal optimization of agents, with the capital stock per worker converging to a level where its marginal product equals the rate of time discounting. In endogenous growth models, however, total factor productivity may be the result of learning-by-doing externalities (see, for example, Lucas 1990 Romer 1993). Assuming

that the endogenous processes that generate capital accumulation and total factor productivity converge to a steady state, we can write steady-state output per worker as

$$
\left(\frac{Y}{L}\right)^{*}=A^{*}\left(\frac{K^{*}}{L}\right)^{\alpha}
$$


where * denotes a variable's steady-state value. The steady state is assumed to be determined by a set of factors, $X$, that may influence total factor productivity and capital accumulation. That is,

$$
y^{*}=X \beta
$$

where $y^{*}$ is steady-state income per worker and $X$ is a matrix of variables that affect the steadystate levels of total factor productivity and capital intensity, and typically includes measures of natural resource abundance, geography, human capital, and economic policy.

The regression equation derived from this model assumes that the actual level of income per worker will adjust slowly from its initial level to this steady-state level according to

$$
g_{y}=\lambda(y *-y)
$$

where $g_{y}$ is the growth rate of output per worker, $y^{*}$ represents the steady-state level of log income per worker, $y$ represents initial log income per worker, and $\lambda$ is the rate of convergence to the steady state. This equation implies that a country's rate of growth is proportional to its initial distance from its steady-state income level, $y^{*}$. The poorer a country is with respect to its steady state, the faster it can be expected to grow. This property of standard neoclassical growth models, in which each country's income continually approaches a ceiling that is determined by that country's characteristics, is known as conditional convergence (see, for example, Barro 1991; Barro and Lee 1994; Barro and Sali-I-Martin 1995; Mankiw, Romer, and Weil 1992; Sachs and Warner 1995). Combining the steady-state equation with the adjustment process and adding a random error $(\varepsilon)$ gives the following equation, whose parameters can be estimated:

$$
g_{y}=\lambda \beta X-\lambda y+\varepsilon
$$

These equations provide the theoretical underpinnings of most recent empirical studies of the sources of economic growth. However, while the equations are written in terms of output per worker (because it is workers who enter the production function), empirically the equations are 
usually specified in terms of income per capita. The simple version of the neoclassical model assumes that every member of the population is a worker, in which case replacing per worker income with per capita income has no effect. Bloom and Williamson (1998) point out that in practice, this approximation is valid only for demographically stable populations. If the age structure of the population is undergoing a transition, then interpreting equation (5A) in per capita terms is no longer valid.

Following Bloom and Williamson, we include age structure effects in the empirical model by using a modification that shifts the unit of analysis from output per worker to output per capita using the following adjustment:

$$
\frac{Y}{P}=\frac{Y}{L} \frac{L}{P}
$$

where $Y$ is output, $P$ is population, and $L$ is labor. Taking natural logs of both sides of equation (6A), we obtain

$$
\tilde{y}=y+\log (L / P)
$$

where $\tilde{y}$ is $\log$ output per capita, y is $\log$ output per worker, and $(\mathrm{L} / \mathrm{P})$ is workers per capita. We can then transform equation $(5 \mathrm{~A})$ using these identities to give the growth rate of income per capita (where g denotes a growth rate) as

$$
g_{\tilde{y}}=-\lambda \tilde{y}+\lambda \log (L / P)+\lambda \beta X+g_{\text {worker } s}-g_{\text {population }}+\varepsilon
$$

If this model, which is specified in per worker terms, is correct, the estimation of growth rates in per capita terms requires the inclusion of demographic variables.

Note that equation (8) differs from the corresponding equation presented in Bloom and Williamson (1998) in that we have initial income per capita and workers per capita as right- 
hand-side variables, while they have initial income per worker, which implicitly constrains the absolute values of the coefficients on $\tilde{y}$ and $\log (\mathrm{L} / \mathrm{P})$ to be equal. This constraint implies that the only effect on the steady state level of income of changes in the age structure is an accounting effect, ruling out any behavioral effects.

In addition, there is an important difference between the implication of our approach and Bloom and Williamson's interpretation of their results. They argue that changes in population and age structure have a purely transitional effect on economic growth, while our decomposition implies that a higher ratio of workers per capita leads to a higher steady-state level of income per capita in the long run.

If the demographic variables matter only in the accounting sense outlined here, then the coefficients on the growth rates of workers and total population are restricted to +1 and -1 respectively, and the coefficient on log workers per capita is equal to the negative of the coefficient on initial income per capita. However, our demographic variables may have real economic effects in terms of income per worker (that is, the demographic variables may appear as part of the vector $X$, the set of variables that determines steady-state income per worker). For example, an increase in the ratio of workers to total population implies a decrease in the dependency rate, which may increase labor force participation. If population growth leaves the ratio of workers to total population unchanged, our accounting framework predicts no change in workers per capita, and therefore no impact on income per capita. However, a rapidly growing work force may affect income per worker if the economy has difficulties in absorbing new workers. For instance, a rapidly growing work force may dilute capital per worker and reduce output per worker. Rather than impose the accounting restrictions in the estimation, we prefer to 
estimate the parameters freely to see if evidence of such effects is apparent. We actually estimate the parameters of the relationship

$$
g_{\tilde{y}}=-\lambda_{1} \tilde{y}+\lambda_{2} \log (L / P)+\lambda_{1} \beta X+\gamma_{1} g_{\text {worker } s}+\gamma_{2} g_{\text {population }}+\varepsilon
$$

One problem with implementing this approach empirically is the lack of data on the number of workers in the economy and the spotty nature of available labor force data. We proxy this by the population of working-age people (those aged 15 to 64). This makes the implicit assumption that the activity rate for people of working age is constant over time. Our work can therefore be seen as a first step toward a comprehensive analysis in that we examine the effects of demographic structure on economic growth, but do not take participation rates among people of working age into account. ${ }^{1}$

In addition to the usual total population growth rate, our approach implies that we should include the growth rate of the working-age population and the ratio of the working-age population to total population as demographic variables that are important determinants of the growth rate of income per capita. We also include life expectancy and population density as demographic variables. Rather than actual population density we use working-age population per unit area, because it is the density of workers that affects steady-state output per worker (our specification already takes account of the effect of workers per capita on the steady state). In addition, we enter our density variable separately for coastal and inland areas, because the effects of density may depend on access to world trade. As noted, these may be important determinants of the steady-state level of income per worker.

\footnotetext{
${ }^{1}$ Most of the working-age population not employed in the labor market tends to be involved in productive activities in the home. The real problem may not be measuring the working population, but measuring household activities in terms of GDP.
} 


\section{References}

Asian Development Bank. 1997. Emerging Asia. Manila.

Azariadis, C. 1996. "The Economics of Development Traps." Journal of Economic Growth 1: 449-85.

Barlow, R. J. 1994. "Population Growth and Economic Growth: Some More Correlations." Population and Development Review 20: 153-65.

Barro, R. J. 1991. "Economic Growth in a Cross-Section of Countries." Quarterly Journal of Economics 106: 501-526.

Barro, R. J., and J.-W. Lee. 1994. "Sources of Economic Growth." Carnegie-Rochester Conference Series on Public Policy. 40: 1-46

Barro, R.J., and X. Sala-i-Martin. 1995. Economic Growth New York: McGraw Hill.

Becker, G. S., and R. J. Barro. 1988. "A Reformulation of the Economic Theory of Fertility." Quarterly Journal of Economics 103: 1-25.

Becker, G. S., K. M. Murphy, and R. Tamura. 1990. "Human Capital, Fertility and Economic Growth.” Journal of Political Economy 98: S12- S37.

Bloom, D. E., and D. Canning. 1999. "From Demographic Lift to Economic Liftoff: The Case of Egypt." Paper presented at the conference on Growth Beyond Stabilization: Prospects for Egypt. February 3-4. Cairo, Egypt.

Bloom, D. E., and R. B. Freeman. 1986. "The Effects of Rapid Population Growth on Labor Supply and Employment in Developing Countries." Population and Development Review 12: 381-414.

1988. "Economic Development and the Timing of Economic Growth." Journal of Policy Modeling 10: 57-81

Bloom, D. E., and J. Sachs. 1998. "Geography, Demography, and Economic Growth in Africa." Brookings Papers on Economic Activity 2: 207-273.

Bloom, D. E., and J. G. Williamson. 1997. "Demographic Change and Human Resource Development." In Asian Development Bank, ed., Emerging Asia. Manila: Asian Development Bank.

1998. "Demographic Transitions and Economic Miracles in Emerging Asia." World Bank Economic Review 12: 419-56. 
Bloom, D. E., D. T. Jamison, P. N. Malaney, and J. P. Ruger. 1998. "Health, Health Policy, and Economic Outcomes." Special Report for the Health and Development Satellite Team of the World Health Organization. Harvard Institute for International Development, Cambridge, Massachusetts, and World Bank, Washington, D.C.

Bongaarts, J. 1994. "The Impact of Population Policies: Comment." Population and Development Review. 20 : 616-20.

Boserup, E. 1981. Population and Technological Change: A Study of Long-Term Trends. Chicago: Chicago University Press.

Brander, J. A., and S. Dowrick. 1994. "The Role of Fertility and Population in Economic Growth: Empirical Results from Aggregate Cross-National Data." Journal of Population Economics 7: 1-25.

Caldwell, J. C. 1982. Theory of Fertility Decline. London: Academic Press.

Cass, D. 1965. "Optimum Growth in an Aggregative Model of Capital Accumulation." Review of Economic Studies 32: 233-40.

Cheng, B. S., and S. L. S. Nwachukwu. 197. "The Effect of Education on Fertility in Taiwan: A Time Series Analysis." Economics Letters 56: 95-99.

Coale, A. J. 1986. "Population Trends and Economic Development." In J. Menken, ed., World Population and U.S. Policy: The Choices Ahead. New York: Norton.

Coale, A. J., and E. Hoover. 1958. Population Growth and Economic Development in LowIncome Countries. Princeton, New Jersey: Princeton University Press.

Ehrlich P. 1968. The Population Bomb New York: Ballantine.

Ehrlich, I., and F. T. Lui 1991. "Intergenerational Trade, Longevity, and Economic Growth." Journal of Political Economy 99: 1029-59.

Fogel, R. W. 1993. "Economic Growth, Population Theory, and Physiology: The Bearing of Long-Term Processes on the Making of Economic Policy." American Economic Review 84: 369-95.

Furman, J., and J. E. Stiglitz. 1998. "Economic Crises: Evidence and Insights from East Asia" Brookings Papers on Economic Activity 2: 1-114.

Gallup, J. L. 1998. “Agricultural Productivity and Geography.” Working Paper Series. Harvard Institute for International Development, Cambridge, Massachusetts. 
Gallup, J. L., J. D. Sachs, and A. Mellinger. 1998. "Geography and Economic Development." Working Paper 6849. National Bureau of Economic Research. Cambridge, Massachusetts.

Gertler, P. J., and J. W. Molyneaux. 1994. "How Economic Development and Family Planning Programs Combined to Reduce Indonesian Fertility.” Demography 31: 33-63.

Hanushek, E. A. 1992. "The Tradeoff between Child Quantity and Quality.” Journal of Political Economy 100: 84-117.

Higgins M. 1998. "The Demographic Determinants of Savings, Investment and International Capital Flows." International Economic Review 39: 343-69.

Higgins, M., and J. G. Williamson. 1997. "Age Structure Dynamics in Asia and Dependence of Foreign Capital." Population and Development Review 23: 261-93.

Islam, N. 1995. "Growth Empirics: A Panel Data Approach." The Quarterly Journal of Economics 110(4): 1127-70.

Kelley A. C., and R. M. Schmidt. 1995. "Aggregate Population and Economic Growth Correlations: The Role of the Components of Demographic Change." Demography 32: 543-55.

. 1996. "Savings, Dependency, and Development." Journal of Population Economics 9: 365-86.

. 1998. "Economic and Demographic Change: A Synthesis of Models, Findings, and Perspectives." Unpublished manuscript. University of Richmond, E. Claiborne Robins School of Business, Richmond, Virginia.

Knack, Stephen, and Philip Keefer. 1995. "Institutions and Economic Performance: CrossCountry Tests Using Alternative Institutional Measures." Economics and Politics 7: 207227.

Knodel, J., and M. Wongsith. 1991. "Family Size and Children's Education in Thailand: Evidence from a National Sample." Demography 28: 119-31.

Knodel, J., N. Havanon, and W. Sittitrai. 1990. "Family Size and the Education of Children in the Context of Rapid Fertility Decline." Population and Development Review 16: 31-56.

Krugman, Paul. 1994. "The Myth of Asia's Miracle." Foreign Affairs 73: 62-78.

Kuznets, S. 1967. "Population and Economic Growth." Proceedings of the American Philosophical Society 111: 170-93. 
Landes, David S. 1998. The Wealth and Poverty of Nations : Why Some Are So Rich and Some So Poor. New York: W. W. Norton.

Lee, R., A. Mason and T. Miller. 1998. "Saving, Wealth and Population" Paper prepared for The Symposium on Population Change and Economic Development cosponsored by the Rockefeller and Packard Foundations and The United Nations Fund for Population Activities (UNFPA) held at Bellagio Center, Lake Como, Italy, November 2-6, 1998.

Leff, R. D. 1969. “Dependency Rates and Savings Rates.” American Economic Review 59: 88696.

Lucas, R. E. 1990. "Why Doesn't Capital Flow from Rich to Poor Countries? (The "New" Growth Theory)." American Economic Review 80: 92-96.

Malthus T.R. 1798. An Essay on the Principle of Population. London: W. Pickering (1986).

Mankiw, N. G., D. Romer, and D. N. Weil. 1992. "A Contribution to the Empirics of Economic Growth.” Quarterly Journal of Economics 107: 407-437.

Manton, K. G. and E. Stallard. 1984. Recent Trends in Mortality Analysis. Orlando: Academic Press.

Mason, Andrew. 1988. "Saving, Economic Growth, and Demographic Change" Population and Development Review 14: 113-44.

Meltzer, D. 1995. "Mortality Decline, the Demographic Transition, and Economic Growth." Unpublished paper. Brigham and Women's Hospital and National Bureau of EconomicResearch, Cambridge, Massachusetts.

Modigliani, F. 1986. "Life-Cycle, Individual Thrift and the Wealth of Nations" American Economic Review 76: 297-313.

Preston, S. 1975. "The Changing Relation between Mortality and the Level of Economic Development." Population Studies 29: 231-48.

1980. "Mortality Declines in Less Developed Countries.” In R. Easterlin, ed., Population and Economic Change in Developing Countries. Chicago: University of Chicago Press.

Pritchett, L. H. 1994. "Desired Fertility and the Impact of Population Policies." Population and Development Review 20: 1-55.

Pritchett, L. H., and L. H. Summers. 1996. "Wealthier Is Healthier." Journal of Human Resources XXXI: 883-55.

Quah, D. T. 1997. "Empirics for Growth and Distribution: Stratification, Polarization, and Convergence Clubs.” Journal of Economic Growth 2:.27-59. 
Radelet, S., and J. D. Sachs. 1998. "The East Asian Financial Crisis: Diagnosis, Remedies, Prospects." Brookings Papers on Economic Activity 1: 1-74.

Radelet, S., J. D. Sachs, and J. W. Lee. 1997. "Economic Growth and Transformation." Development Discussion Paper no. 609. Harvard Institute for International Development, Cambridge, Massachusetts.

Rodrik, D. 1994. "King Kong Meets Godzilla: The World Bank and The East Asian Miracle." In A. Fishlow, C. Gwin, S. Haggard, and R. Wade, eds., Miracle or Design? Lessons from the East Asian Experience. Policy Essay no. 11. Washington, D.C.: Overseas Development Council.

. 1998. "TFPG Controversies, Institutions, and Economic Performance in East Asia." In Y. Hayami and M. Aoki, eds., The Institutional Foundation of Economic Development in East Asia. London: Macmillan.

Romer, P. M. 1993. "Idea Gaps and Object Gaps in Economic Development." Journal of Monetary Economics 32: 543-73.

Rosenzweig, M. R. 1990. "Population Growth and Human Capital Investments: Theory and Evidence." Journal of Political Economy 98: S38-S70.

Sachs, Jeffrey D., and Andrew Warner. 1995. "Economic Reform and the Process of Global Integration." Brookings Papers on Economic Activity 1: 1-118.

1997. "Sources of Slow Growth in African Economies." Journal of African Economies 6: 335-76.

Schultz, T. P. 1994. "Human Capital, Family Planning, and Their Effects on Population Growth." American Economic Review, Papers, and Proceedings 84: 255-60.

Simon, J. 1981. The Ultimate Resource. Princeton: Princeton University Press.

Strauss, J. and T. Duncan. 1995. "Health and Labour Productivity: Sorting out the Relationships." In G. H. Peters and D. D. Hedley, eds., Agricultural Competitiveness: Market Forces and Policy Choice: Proceedings of the Twenty-Second International Conference of Agricultural Economists. International Association of Agricultural Economists Series. Aldershot, U.K.: Dartmouth.

Strauss, J., and D. Thomas. 1998. "Health, Nutrition, and Economic Development." Journal of Economic Literature 36: 766-817.

Summers, R., and A. Heston. 1991. "The Penn World Table (Mark 5): An Expanded Set of International Comparisons, 1950-1988." Quarterly Journal of Economics 106: 327-368. 
Wang, J., and D. T. Jamison. 1997. "Education and Income as Determinants of Fertility: Regional and Temporal Variation in Effects." Unpublished manuscript. World Bank, Washington, D.C.

Webb, S., and H. Zia. 1990. "Lower Birth Rates = Higher Savings in LDCs." Finance and Development 27: 12-14.

World Bank. 1993. The East Asian Miracle: Economic Growth and Public Policy. New York: Oxford University Press.

Young, Alwyn. 1994. "Lessons from the East Asian NICS: A Contrarian View." European Economic Review 38: 964-73.

1995. "The Tyranny of Numbers: Confronting the Statistical Realities of the East Asian Growth Experience." The Quarterly Journal of Economics 110(3): 641-80. 
Figure 1: Conditional Convergence Model of Economic Growth

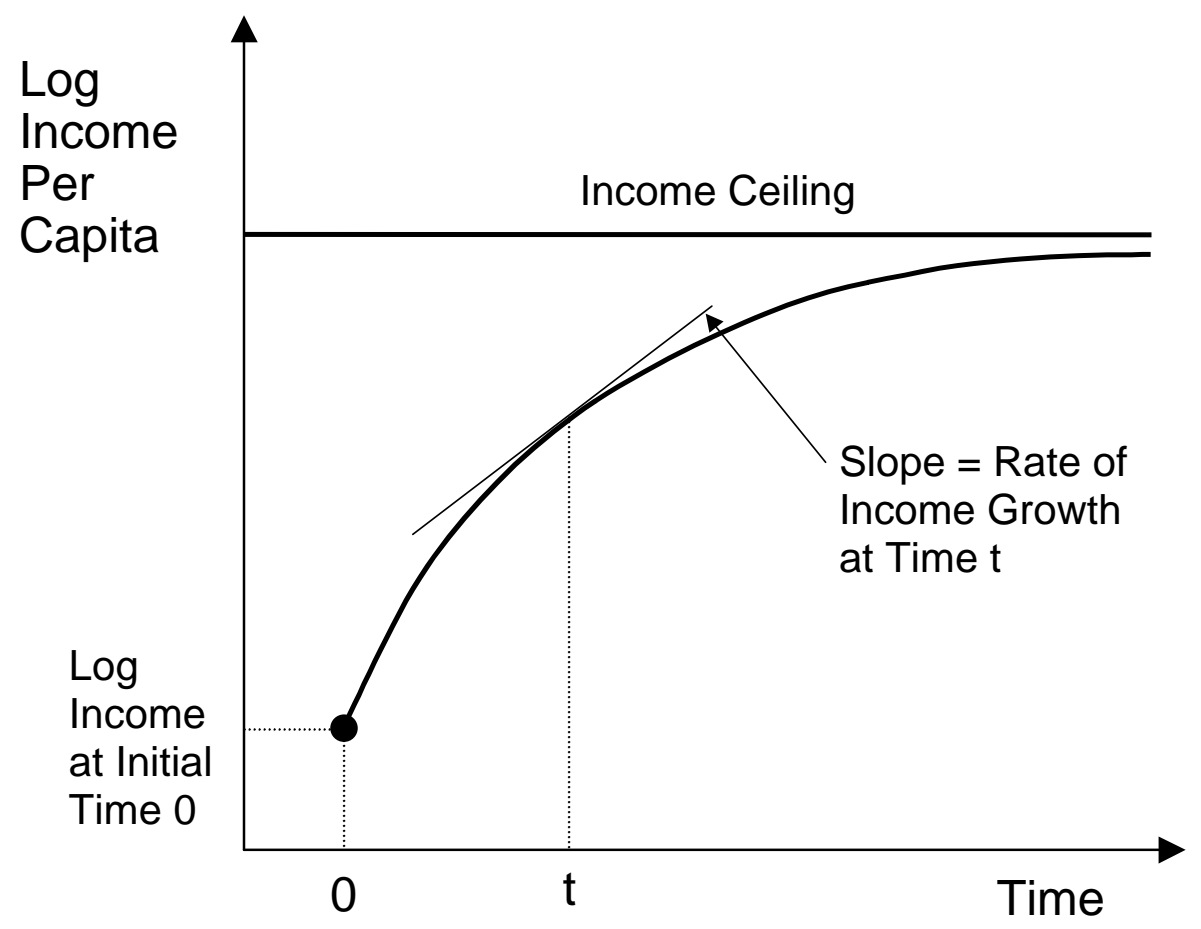


Table 1: Sectoral structure in developing regions, 1970 to 1990

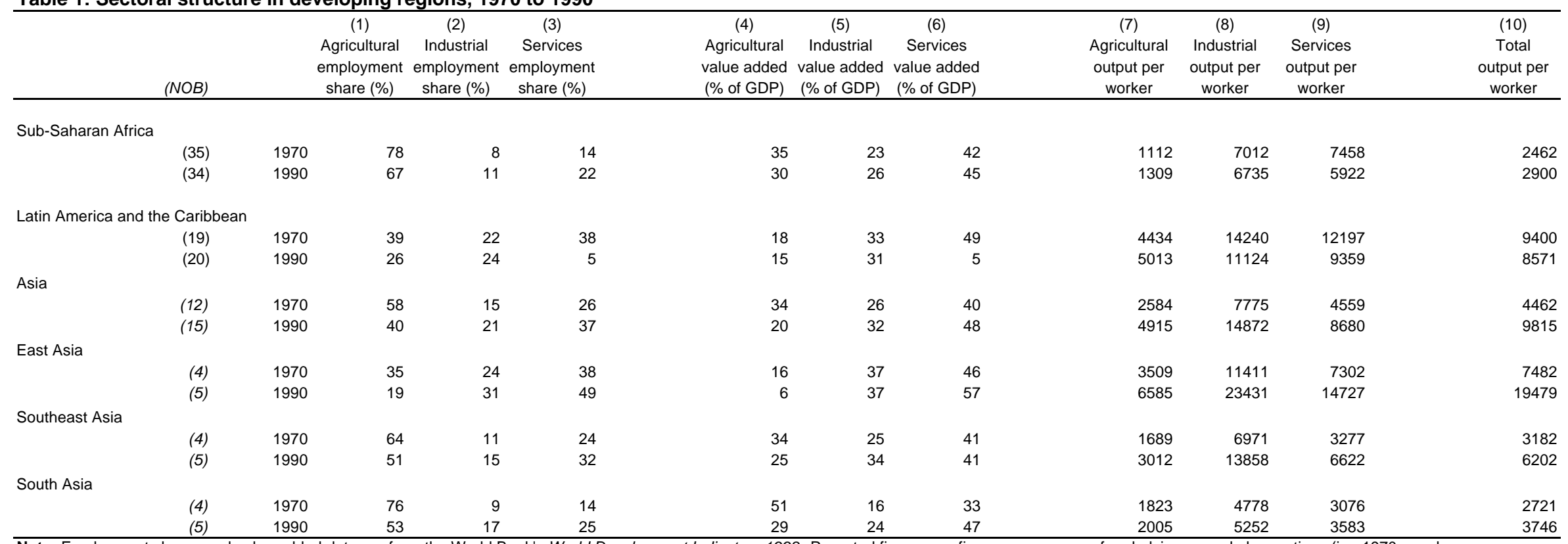

作

the average for 1970-75). Output per worker was calculated using labor force data from the World Bank and GDP data from Summers and Heston (1991), (version 5.6 update of the PENN World Tables).

The values for output per worker by sector were then calculated by multiplying average output per worker by the ratio of value added to employment for each sector. 
Table 2: Labor force participation and age structure in developing regions, 1970 to 1990

\begin{tabular}{|c|c|c|c|c|c|}
\hline & & $\begin{array}{c}(1) \\
\text { Labor force } \\
\text { participation } \\
\text { ratio }\end{array}$ & $\begin{array}{c}(2) \\
\text { Working age } \\
\text { to total } \\
\text { age ratio }\end{array}$ & $\begin{array}{l}\text { (3) } \\
\text { Output } \\
\text { per } \\
\text { worker }\end{array}$ & $\begin{array}{c}(4)=(1)(2)(3) \\
\text { Output } \\
\text { per } \\
\text { capita }\end{array}$ \\
\hline \multirow[t]{2}{*}{ Sub-Saharan Africa } & 1970 & 0.89 & 0.53 & 2462 & 1161 \\
\hline & 1990 & 0.87 & 0.52 & 2900 & 1312 \\
\hline \multirow[t]{2}{*}{ Latin America and the Carib } & 1970 & 0.64 & 0.52 & 9400 & 3128 \\
\hline & 1990 & 0.66 & 0.57 & 8571 & 3224 \\
\hline \multirow[t]{2}{*}{ Asia } & 1970 & 0.73 & 0.55 & 4462 & 1792 \\
\hline & 1990 & 0.76 & 0.62 & 9815 & 4709 \\
\hline \multirow[t]{2}{*}{ East Asia } & 1970 & 0.73 & 0.59 & 7482 & 3259 \\
\hline & 1990 & 0.74 & 0.69 & 19479 & 9777 \\
\hline \multirow[t]{2}{*}{ Southeast Asia } & 1970 & 0.75 & 0.53 & 3182 & 1173 \\
\hline & 1990 & 0.78 & 0.59 & 6202 & 2763 \\
\hline \multirow[t]{2}{*}{ South Asia } & 1970 & 0.71 & 0.53 & 2721 & 945 \\
\hline & 1990 & 0.73 & 0.57 & 3746 & 1529 \\
\hline
\end{tabular}

Note: Output per worker is as reported in Table 1 above, output per capita is based on GDP data from

Summers and Heston (1991) and population data from the World Bank's World Development Indicators 1998.

The labor force participation ratio equals the ratio of the total labor force to the total working age

population (i.e. age 15 to 64 ). Both the labor force participation ratio and the working age to total ratio are

based on World Bank data. 
Table 3: Population, labor force, and productivity growth by sector in developing regions, 1970 to 1990

\begin{tabular}{|c|c|c|c|c|c|c|c|c|c|}
\hline & & $\begin{array}{c}(1) \\
\text { Population } \\
\text { growth }\end{array}$ & $\begin{array}{c}\text { (2) } \\
\text { Working age } \\
\text { population } \\
\text { growth }\end{array}$ & $\begin{array}{l}\text { (3) } \\
\text { Labor } \\
\text { force } \\
\text { growth }\end{array}$ & $\begin{array}{l}\text { (4) } \\
\text { Agricultural } \\
\text { productivity } \\
\text { growth }\end{array}$ & $\begin{array}{c}(5) \\
\text { Industrial } \\
\text { productivity } \\
\text { growth }\end{array}$ & $\begin{array}{c}(6) \\
\text { Services } \\
\text { productivity } \\
\text { growth }\end{array}$ & $\begin{array}{l}\text { (7) } \\
\text { Labor } \\
\text { productivity } \\
\text { growth }\end{array}$ & $\begin{array}{c}(8) \\
\text { Growth of } \\
\text { GDP per } \\
\text { capita }\end{array}$ \\
\hline Sub-Saharan Africa & $1970-90$ & $2.7 \%$ & $2.7 \%$ & $2.4 \%$ & $0.7 \%$ & $-1.0 \%$ & $-2.1 \%$ & $0.5 \%$ & $0.2 \%$ \\
\hline Latin America and the Caribbean & $1970-90$ & $1.7 \%$ & $2.5 \%$ & $2.8 \%$ & $0.3 \%$ & $-1.3 \%$ & $-1.6 \%$ & $-0.6 \%$ & $0.4 \%$ \\
\hline Asia & $1970-90$ & $2.1 \%$ & $2.6 \%$ & $2.8 \%$ & $1.8 \%$ & $2.7 \%$ & $1.9 \%$ & $2.7 \%$ & $3.4 \%$ \\
\hline East Asia & $1970-90$ & $1.5 \%$ & $2.3 \%$ & $2.4 \%$ & $2.2 \%$ & $3.6 \%$ & $3.9 \%$ & $4.3 \%$ & $5.2 \%$ \\
\hline Southeast Asia & $1970-90$ & $2.3 \%$ & $2.8 \%$ & $2.7 \%$ & $2.6 \%$ & $2.2 \%$ & $1.3 \%$ & $2.9 \%$ & $3.3 \%$ \\
\hline South Asia & $1970-90$ & $2.5 \%$ & $2.6 \%$ & $3.2 \%$ & $0.5 \%$ & $0.5 \%$ & $0.8 \%$ & $0.9 \%$ & $1.7 \%$ \\
\hline
\end{tabular}

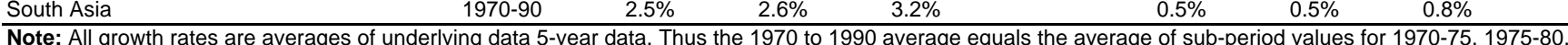

1980-85, 1985-90. This method incorporates more information into the results as some countries are missing data for the first and/or last periods. All sub-periods

with complete information were averaged into the above results. A second advantage of this approach is that it takes into account changes in the allocation of labor

more frequently than a simple average of 1970 to 1990 (with 1970 labor share weights). Therefore the method does not exaggerate the contribution of labor re-allocation

to aggregate economic growth. 
Table 4a: Sources of growth in developing regions, 1970 to 1990

\begin{tabular}{|c|c|c|c|c|c|c|}
\hline \multicolumn{7}{|c|}{ Components of GDP per capita growth } \\
\hline & (1) & (2) & (3) & (4) & (5) & (6) \\
\hline & Sub-Saharan & Latin & All Asia & East Asia & Southeast & South \\
\hline & Africa & America & & & Asia & Asia \\
\hline Agricultural productivity growth & 0.5 & 0.1 & 1.0 & 0.8 & 1.7 & 0.4 \\
\hline Industrial productivity growth & -0.1 & -0.3 & 0.4 & 0.9 & 0.3 & 0.0 \\
\hline Services productivity growth & -0.3 & -0.6 & 0.5 & 1.5 & 0.3 & 0.1 \\
\hline Labor re-allocation effect & 0.3 & 0.2 & 0.8 & 1.1 & 0.7 & 0.4 \\
\hline Labor force participation & -0.3 & 0.3 & 0.2 & 0.1 & 0.0 & 0.6 \\
\hline Changes in age structure & 0.0 & 0.8 & 0.5 & 0.7 & 0.4 & 0.2 \\
\hline Productivity growth & 0.2 & -0.8 & 1.9 & 3.2 & 2.2 & 0.5 \\
\hline Pure labor effect & 0.0 & 1.2 & 1.5 & 2.0 & 1.1 & 1.1 \\
\hline Total & 0.2 & 0.4 & 3.4 & 5.2 & 3.3 & 1.7 \\
\hline
\end{tabular}

$\begin{array}{llllll}0.2 & 0.4 & 3.4 & 5.2 & 3.3\end{array}$ 
Table 4b: Sources of growth in Asia, 1970 to 1990

\begin{tabular}{|c|c|c|c|c|}
\hline & \multicolumn{4}{|c|}{ Percent contribution to GDP per capita growth } \\
\hline & (1) & (2) & (3) & (4) \\
\hline & All Asia & East Asia & Southeast & South \\
\hline & & & Asia & Asia \\
\hline Agricultural productivity growth & $31 \%$ & $15 \%$ & $51 \%$ & $21 \%$ \\
\hline Industrial productivity growth & $12 \%$ & $17 \%$ & $8 \%$ & $3 \%$ \\
\hline Services productivity growth & $15 \%$ & $29 \%$ & $10 \%$ & $6 \%$ \\
\hline Labor re-allocation effect & $22 \%$ & $22 \%$ & $20 \%$ & $22 \%$ \\
\hline Labor force participation & $6 \%$ & $3 \%$ & $-1 \%$ & $35 \%$ \\
\hline Changes in age structure & $14 \%$ & $14 \%$ & $13 \%$ & $11 \%$ \\
\hline Productivity growth & $57 \%$ & $61 \%$ & $67 \%$ & $31 \%$ \\
\hline Pure labor effect & $43 \%$ & $39 \%$ & $33 \%$ & $69 \%$ \\
\hline Total & $100 \%$ & $100 \%$ & $100 \%$ & $100 \%$ \\
\hline
\end{tabular}


Table 5: Explaining cross country economic growth, 1965-90

Dependent variable: Annual average growth rate of real GDP per capita, 1965-90, in PPP terms

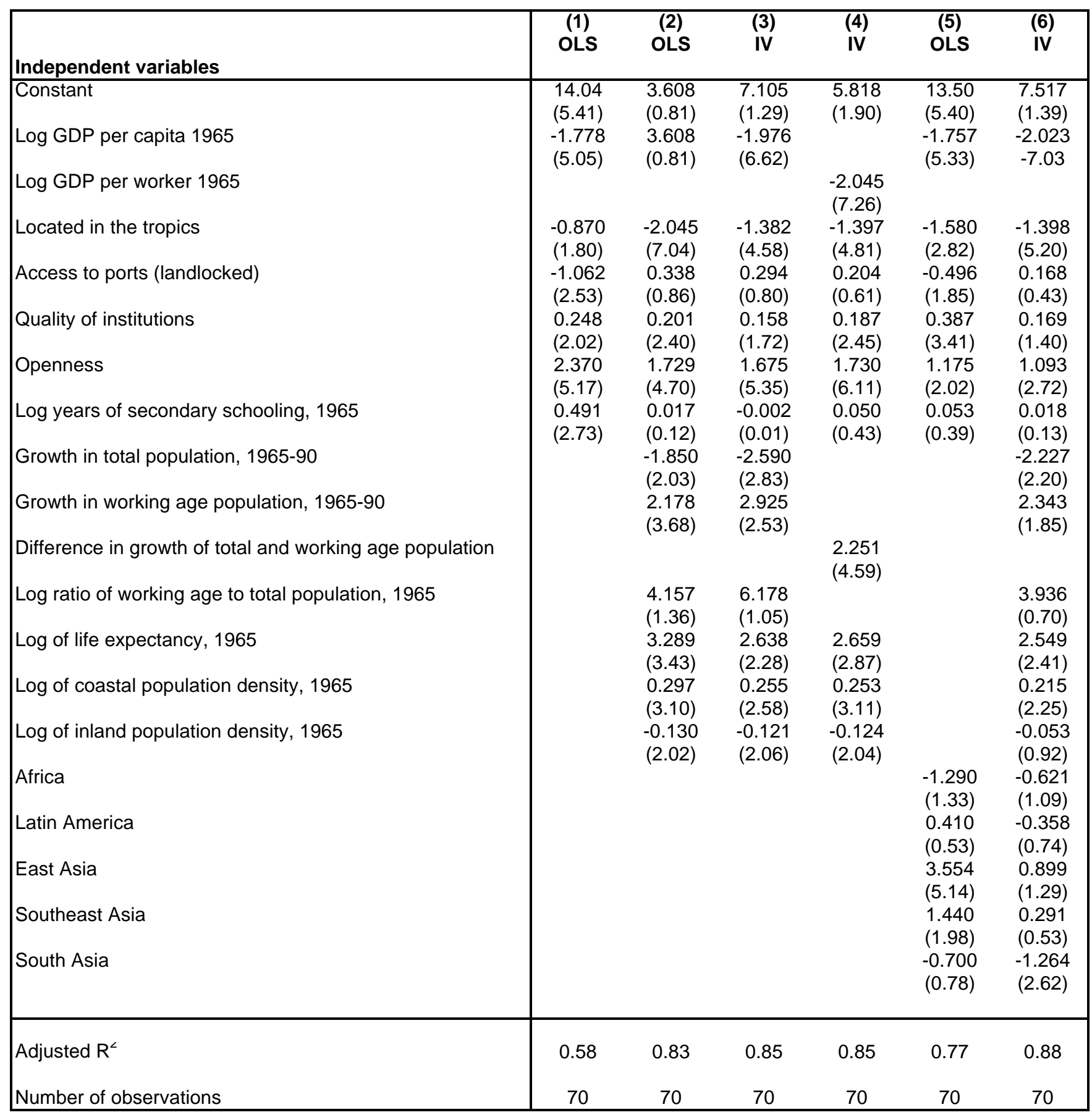

Note: The growth of the total population and the working age population (and their differences) have been instrumented using fertility in 1965 and growth rates of population and working age population, 1960-65

Heteroskedasticity-consistent t statistics are reported in parentheses below the coefficient estimates. 
Table 6: Explaining cross country economic growth, 1965-90

Dependent Variable: Annual average percentage growth rate of real GDP per capita in PPP terms in 5 year period

\begin{tabular}{|c|c|c|c|c|c|c|}
\hline Independent Variables & $\begin{array}{l}(1) \\
\text { OLS }\end{array}$ & $\begin{array}{c}(2) \\
\text { OLS }\end{array}$ & $\begin{array}{l}\text { (3) } \\
\text { IV }\end{array}$ & $\begin{array}{l}\text { (4) } \\
\text { IV }\end{array}$ & $\begin{array}{l}\text { (5) } \\
\text { OLS }\end{array}$ & $\begin{array}{l}\text { (6) } \\
\text { IV }\end{array}$ \\
\hline Constant & $\begin{array}{l}12.76 \\
(5.74)\end{array}$ & $\begin{array}{l}-6.342 \\
(1.03)\end{array}$ & $\begin{array}{l}-3.804 \\
(0.62)\end{array}$ & $\begin{array}{c}-4.672 \\
(0.85)\end{array}$ & $\begin{array}{l}14.52 \\
(4.81)\end{array}$ & $\begin{array}{r}-1.009 \\
(0.13)\end{array}$ \\
\hline Log GDP per capita in base year & $\begin{array}{r}-1.690 \\
(5.78)\end{array}$ & $\begin{array}{r}-2.280 \\
(6.30)\end{array}$ & $\begin{array}{l}-2.213 \\
(6.12)\end{array}$ & & $\begin{array}{l}-1.933 \\
(4.81)\end{array}$ & $\begin{array}{l}-2.205 \\
(5.36)\end{array}$ \\
\hline GDP per worker in base year & & & & $\begin{array}{c}-2.253 \\
(6.43)\end{array}$ & & \\
\hline Located in the tropics & $\begin{array}{l}-1.085 \\
(2.57)\end{array}$ & $\begin{array}{c}-1.139 \\
(2.63)\end{array}$ & $\begin{array}{r}-1.270 \\
(2.61)\end{array}$ & $\begin{array}{l}-1.141 \\
(2.68)\end{array}$ & $\begin{array}{c}-1.083 \\
(2.35)\end{array}$ & $\begin{array}{r}-1.230 \\
(2.50)\end{array}$ \\
\hline Landlocked & $\begin{array}{c}-0.358 \\
(0.87)\end{array}$ & $\begin{array}{l}-0.016 \\
(0.04)\end{array}$ & $\begin{array}{l}0.044 \\
(0.12)\end{array}$ & $\begin{array}{l}-0.048 \\
(0.13)\end{array}$ & $\begin{array}{c}0.108 \\
(0.266)\end{array}$ & $\begin{array}{l}0.079 \\
(0.22)\end{array}$ \\
\hline Quality of institutions & $\begin{array}{l}0.249 \\
(2.22)\end{array}$ & $\begin{array}{l}0.237 \\
(2.10)\end{array}$ & $\begin{array}{l}0.211 \\
(1.84)\end{array}$ & $\begin{array}{l}0.230 \\
(2.09)\end{array}$ & $\begin{array}{l}0.392 \\
(2.87)\end{array}$ & $\begin{array}{l}0.244 \\
(1.81)\end{array}$ \\
\hline Openness over 5 year period & $\begin{array}{l}2.455 \\
(6.05)\end{array}$ & $\begin{array}{l}2.058 \\
(4.85)\end{array}$ & $\begin{array}{l}2.069 \\
(4.76)\end{array}$ & $\begin{array}{l}2.047 \\
(5.03)\end{array}$ & $\begin{array}{l}1.738 \\
(3.98)\end{array}$ & $\begin{array}{l}1.825 \\
(3.93)\end{array}$ \\
\hline Log years of secondary schooling in base year & $\begin{array}{l}0.724 \\
(2.98)\end{array}$ & $\begin{array}{l}0.016 \\
(0.07)\end{array}$ & $\begin{array}{l}-0.035 \\
(0.15)\end{array}$ & $\begin{array}{l}0.017 \\
(0.08)\end{array}$ & $\begin{array}{l}0.228 \\
(0.93)\end{array}$ & $\begin{array}{r}-0.067 \\
(0.29)\end{array}$ \\
\hline Growth in total population over 5 year period & & $\begin{array}{l}-0.980 \\
(2.13)\end{array}$ & $\begin{array}{r}-1.300 \\
(2.39)\end{array}$ & & & $\begin{array}{r}-1.188 \\
(2.13)\end{array}$ \\
\hline Growth in working age population over 5 year period & & $\begin{array}{l}1.265 \\
(3.34)\end{array}$ & $\begin{array}{l}1.750 \\
(3.47)\end{array}$ & & & $\begin{array}{l}1.515 \\
(2.66)\end{array}$ \\
\hline Difference in growth of total and working age population & & & & $\begin{array}{l}1.550 \\
(3.29)\end{array}$ & & \\
\hline Log ratio of working age to total population in base year & & $\begin{array}{l}4.094 \\
(1.12)\end{array}$ & $\begin{array}{l}6.144 \\
(1.49)\end{array}$ & & & $\begin{array}{l}4.317 \\
(0.92)\end{array}$ \\
\hline Log life expectancy in base year & & $\begin{array}{l}6.274 \\
(3.86)\end{array}$ & $\begin{array}{l}5.734 \\
(3.58)\end{array}$ & $\begin{array}{l}5.681 \\
(3.59)\end{array}$ & & $\begin{array}{l}4.834 \\
(2.78)\end{array}$ \\
\hline Population density in base year & & $\begin{array}{l}0.167 \\
(1.76)\end{array}$ & $\begin{array}{l}0.153 \\
(1.63)\end{array}$ & $\begin{array}{l}0.147 \\
(1.52)\end{array}$ & & $\begin{array}{l}0.066 \\
(0.63)\end{array}$ \\
\hline Africa & & & & & $\begin{array}{l}-2.191 \\
(3.48)\end{array}$ & $\begin{array}{c}-0.880 \\
(1.34)\end{array}$ \\
\hline Latin America & & & & & $\begin{array}{l}-0.065 \\
(0.131)\end{array}$ & $\begin{array}{c}-0.292 \\
(0.56)\end{array}$ \\
\hline East Asia & & & & & $\begin{array}{l}2.698 \\
(4.28)\end{array}$ & $\begin{array}{l}1.320 \\
(1.44)\end{array}$ \\
\hline Southeast Asia & & & & & $\begin{array}{l}0.558 \\
(0.81)\end{array}$ & $\begin{array}{l}0.126 \\
(0.17)\end{array}$ \\
\hline South Asia & & & & & $\begin{array}{l}-0.946 \\
(1.11)\end{array}$ & $\begin{array}{c}-0.974 \\
(1.17)\end{array}$ \\
\hline Dummy 1965-1970 & $\begin{array}{l}2.099 \\
(5.41)\end{array}$ & $\begin{array}{l}2.537 \\
(6.85)\end{array}$ & $\begin{array}{l}2.642 \\
(7.30)\end{array}$ & $\begin{array}{c}2.536 \\
(7.017)\end{array}$ & $\begin{array}{l}1.535 \\
(3.89)\end{array}$ & $\begin{array}{l}2.332 \\
(5.61)\end{array}$ \\
\hline Dummy 1970-1975 & $\begin{array}{l}1.592 \\
(3.55)\end{array}$ & $\begin{array}{l}1.735 \\
(4.26)\end{array}$ & $\begin{array}{l}1.739 \\
(4.40)\end{array}$ & $\begin{array}{c}1.670 \\
(4.13)\end{array}$ & $\begin{array}{l}1.173 \\
(2.71)\end{array}$ & $\begin{array}{l}1.536 \\
(3.77)\end{array}$ \\
\hline Dummy 1975-1980 & $\begin{array}{l}1.319 \\
(3.16)\end{array}$ & $\begin{array}{l}1.311 \\
(3.16)\end{array}$ & $\begin{array}{l}1.278 \\
(3.14)\end{array}$ & $\begin{array}{l}1.246 \\
(3.06)\end{array}$ & $\begin{array}{l}0.997 \\
(2.43)\end{array}$ & $\begin{array}{l}1.136 \\
(2.71)\end{array}$ \\
\hline Dummy 1980-1985 & $\begin{array}{l}-0.807 \\
(2.21)\end{array}$ & $\begin{array}{l}-0.880 \\
(2.46)\end{array}$ & $\begin{array}{l}-0.934 \\
(2.61)\end{array}$ & $\begin{array}{l}-0.933 \\
(2.61)\end{array}$ & $\begin{array}{l}-0.963 \\
(2.76)\end{array}$ & $\begin{array}{c}-0.997 \\
(2.76)\end{array}$ \\
\hline Adjusted $\mathrm{R}^{2}$ & 0.30 & 0.39 & 0.38 & 0.39 & 0.37 & 0.39 \\
\hline Number of observations & 391 & 391 & 391 & 391 & 391 & 391 \\
\hline
\end{tabular}

Note: Growth rates of working age and total population in each 5 year period are instrumented with their growth rates over the previous five years and fertility and infant mortality rates in the base year.

Heteroskedasticity-consistent t statistics are reported in parentheses below the coefficient estimates. 
Table 7: The effect of income on life expectancy 1965-1990

Dependent variable: Log life expectancy

\begin{tabular}{|c|c|c|c|c|c|}
\hline $\begin{array}{l}\text { Regression } \\
\text { Estimation method }\end{array}$ & $\begin{array}{c}\text { (1) } \\
\text { OLS }\end{array}$ & $\begin{array}{c}(2) \\
\begin{array}{c}\text { Instrumental } \\
\text { variables }\end{array}\end{array}$ & $\begin{array}{c}\text { (3) } \\
\text { Instrumental } \\
\text { variables }\end{array}$ & $\begin{array}{l}\text { (4) } \\
\text { OLS }\end{array}$ & $\begin{array}{c}(5) \\
\text { Instrumental } \\
\text { variables }\end{array}$ \\
\hline Constant & $\begin{array}{l}2.671 \\
(64.3)\end{array}$ & $\begin{array}{l}2.471 \\
(44.6)\end{array}$ & $\begin{array}{l}2.873 \\
(22.0)\end{array}$ & $\begin{array}{c}\text { Fixed } \\
\text { Effects }\end{array}$ & $\begin{array}{l}\text { Fixed } \\
\text { Effects }\end{array}$ \\
\hline Log GDP per worker & $\begin{array}{l}0.165 \\
(44.0)\end{array}$ & $\begin{array}{l}0.188 \\
(34.4)\end{array}$ & $\begin{array}{l}0.145 \\
(11.2)\end{array}$ & $\begin{array}{c}-0.002 \\
(0.11)\end{array}$ & $\begin{array}{l}-0.008 \\
(0.21)\end{array}$ \\
\hline Dummy 1965 & $\begin{array}{l}-0.059 \\
(3.28)\end{array}$ & $\begin{array}{l}-0.050 \\
(2.74)\end{array}$ & $\begin{array}{l}-0.072 \\
(4.05)\end{array}$ & $\begin{array}{l}-0.137 \\
(11.0)\end{array}$ & $\begin{array}{l}-0.141 \\
(7.23)\end{array}$ \\
\hline Dummy 1970 & $\begin{array}{l}-0.047 \\
(2.80)\end{array}$ & $\begin{array}{l}-0.041 \\
(2.39)\end{array}$ & $\begin{array}{l}-0.055 \\
(3.49)\end{array}$ & $\begin{array}{l}-0.099 \\
(8.75)\end{array}$ & $\begin{array}{l}-0.101 \\
(7.43)\end{array}$ \\
\hline Dummy 1975 & $\begin{array}{r}-0.044 \\
(2.72)\end{array}$ & $\begin{array}{l}-0.040 \\
(2.39)\end{array}$ & $\begin{array}{l}-0.047 \\
(3.19)\end{array}$ & $\begin{array}{r}-0.065 \\
(6.16)\end{array}$ & $\begin{array}{l}-0.067 \\
(6.46)\end{array}$ \\
\hline Dummy 1980 & $\begin{array}{l}-0.038 \\
(2.39)\end{array}$ & $\begin{array}{l}-0.035 \\
(2.18)\end{array}$ & $\begin{array}{l}-0.038 \\
(2.59)\end{array}$ & $\begin{array}{c}-0.034 \\
(3.24)\end{array}$ & $\begin{array}{l}-0.034 \\
(3.83)\end{array}$ \\
\hline Dummy 1985 & $\begin{array}{r}-0.006 \\
(0.39)\end{array}$ & $\begin{array}{r}-0.003 \\
(0.21)\end{array}$ & $\begin{array}{l}-0.006 \\
(0.43)\end{array}$ & $\begin{array}{l}-0.004 \\
(0.37)\end{array}$ & $\begin{array}{r}-0.004 \\
(0.45)\end{array}$ \\
\hline Africa & & & $\begin{array}{l}-0.091 \\
(3.22)\end{array}$ & & \\
\hline Latin America & & & $\begin{array}{l}-0.003 \\
(0.25)\end{array}$ & & \\
\hline South Asia & & & $\begin{array}{l}0.005 \\
(0.16)\end{array}$ & & \\
\hline Sout East Asia & & & $\begin{array}{l}0.061 \\
(2.82)\end{array}$ & & \\
\hline East Asia & & & $\begin{array}{l}0.089 \\
(6.34)\end{array}$ & & \\
\hline Number of obsevations & 569 & 569 & 569 & 569 & 569 \\
\hline Number of countries & 107 & 107 & 107 & 107 & 107 \\
\hline R squared adjusted & 0.76 & 0.76 & 0.81 & 0.94 & 0.94 \\
\hline
\end{tabular}

Log GDP per worker is instrumented with: log black market premium, log openness, log distance to major market, landlocked dummy, and percent land with $100 \mathrm{~km}$ of coast

Heteroskedasticity-consistent t statistics are reported in parentheses below the coefficient estimates. 
Table 8: The effect of income on fertility rates 1965-1990

Dependent variable: Log fertility

\begin{tabular}{|c|c|c|c|c|c|}
\hline $\begin{array}{l}\text { Regression } \\
\text { Estimation method }\end{array}$ & $\begin{array}{l}(1) \\
\text { OLS }\end{array}$ & $\begin{array}{c}(2) \\
\text { Instrumental } \\
\text { variables }\end{array}$ & $\begin{array}{c}\text { (3) } \\
\text { Instrumental } \\
\text { variables }\end{array}$ & $\begin{array}{l}(4) \\
\text { OLS }\end{array}$ & $\begin{array}{c}(5) \\
\text { Instrumental } \\
\text { variables }\end{array}$ \\
\hline Constant & $\begin{array}{l}4.502 \\
(40.3)\end{array}$ & $\begin{array}{l}5.539 \\
(35.2)\end{array}$ & $\begin{array}{l}4.877 \\
(9.47)\end{array}$ & $\begin{array}{l}\text { Fixed } \\
\text { effects }\end{array}$ & $\begin{array}{l}\text { Fixed } \\
\text { effects }\end{array}$ \\
\hline Log GDP per worker & $\begin{array}{c}-0.374 \\
(30.5)\end{array}$ & $\begin{array}{l}-0.491 \\
(28.6)\end{array}$ & $\begin{array}{l}-0.418 \\
(8.07)\end{array}$ & $\begin{array}{c}-0.196 \\
(4.75)\end{array}$ & $\begin{array}{c}-0.223 \\
(2.44)\end{array}$ \\
\hline Dummy 1965 & $\begin{array}{l}0.260 \\
(5.36)\end{array}$ & $\begin{array}{l}0.219 \\
(4.03)\end{array}$ & $\begin{array}{l}0.233 \\
(4.54)\end{array}$ & $\begin{array}{l}0.315 \\
(11.5)\end{array}$ & $\begin{array}{l}0.301 \\
(6.74)\end{array}$ \\
\hline Dummy 1970 & $\begin{array}{l}0.226 \\
(4.66)\end{array}$ & $\begin{array}{l}0.193 \\
(3.80)\end{array}$ & $\begin{array}{l}0.206 \\
(4.43)\end{array}$ & $\begin{array}{l}0.261 \\
(12.2)\end{array}$ & $\begin{array}{l}0.252 \\
(8.37)\end{array}$ \\
\hline Dummy 1975 & $\begin{array}{l}0.198 \\
(4.08)\end{array}$ & $\begin{array}{l}0.173 \\
(3.46)\end{array}$ & $\begin{array}{l}0.182 \\
(4.11)\end{array}$ & $\begin{array}{l}0.202 \\
(10.3)\end{array}$ & $\begin{array}{l}0.198 \\
(9.65)\end{array}$ \\
\hline Dummy 1980 & $\begin{array}{l}0.173 \\
(3.65)\end{array}$ & $\begin{array}{l}0.158 \\
(3.27)\end{array}$ & $\begin{array}{l}0.162 \\
(3.72)\end{array}$ & $\begin{array}{l}0.150 \\
(7.91)\end{array}$ & $\begin{array}{l}0.150 \\
(9.21)\end{array}$ \\
\hline Dummy 1985 & $\begin{array}{l}0.097 \\
(2.09)\end{array}$ & $\begin{array}{l}0.084 \\
(1.77)\end{array}$ & $\begin{array}{l}0.087 \\
(2.01)\end{array}$ & $\begin{array}{l}0.075 \\
(3.64)\end{array}$ & $\begin{array}{l}0.075 \\
(4.23)\end{array}$ \\
\hline Africa & & & $\begin{array}{l}0.002 \\
(0.02)\end{array}$ & & \\
\hline Latin America & & & $\begin{array}{l}0.251 \\
(5.09)\end{array}$ & & \\
\hline South Asia & & & $\begin{array}{r}-0.084 \\
(0.79)\end{array}$ & & \\
\hline Sout East Asia & & & $\begin{array}{c}-0.149 \\
(1.50)\end{array}$ & & \\
\hline East Asia & & & $\begin{array}{l}-0.391 \\
(7.45)\end{array}$ & & \\
\hline Number of obsevations & 569 & 569 & 569 & 569 & 569 \\
\hline Number of countries & 107 & 107 & 107 & 107 & 107 \\
\hline $\mathrm{R}$ squared adjusted & 0.6 & 0.60 & 0.66 & 0.95 & 0.95 \\
\hline
\end{tabular}

Log GDP per worker is instrumented with: log black market premium, log openness, log distance to major market, landlocked dummy, and percent land with $100 \mathrm{~km}$ of coast

Heteroskedasticity-consistent t statistics are reported in parentheses below the coefficient estimates. 
Table 9: Determinants of growth in Asia

\begin{tabular}{|c|c|c|c|c|c|c|c|c|}
\hline & \multicolumn{2}{|c|}{ World } & \multicolumn{2}{|c|}{ E. Asia } & \multicolumn{2}{|c|}{ S.E. Asia } & \multicolumn{2}{|c|}{ S. Asia } \\
\hline & 1965 & 1995 & 1965 & 1995 & 1965 & 1995 & 1965 & 1995 \\
\hline Life expectancy & 52.3 & 64.3 & 63.2 & 74.5 & 49.9 & 63.7 & 46.0 & 59.8 \\
\hline Fertility rate & 4.95 & 2.96 & 4.37 & 1.84 & 6.00 & 3.59 & 6.27 & 4.73 \\
\hline Age dependency ratio & 0.77 & 0.62 & 0.78 & 0.48 & 0.88 & 0.68 & 0.84 & 0.81 \\
\hline Labor force participation & 0.78 & 0.77 & 0.75 & 0.76 & 0.86 & 0.82 & 0.75 & 0.79 \\
\hline Growth in total population & 1.83 & 1.48 & 1.74 & 1.02 & 2.24 & 1.73 & 2.25 & 1.89 \\
\hline Growth in working age population & 2.13 & 1.70 & 2.41 & 1.20 & 2.63 & 2.32 & 2.43 & 2.33 \\
\hline Growth in working age minus total population & 0.30 & 0.22 & 0.68 & 0.18 & 0.39 & 0.59 & 0.18 & 0.44 \\
\hline Real GDP per capita & 2856 & 5077 & 2296 & 9777 & 1164 & 3110 & 989 & 1536 \\
\hline Total years of education, working age population & 3.89 & 5.83 & 5.89 & 8.49 & 2.93 & 5.13 & 1.6 & 3.62 \\
\hline
\end{tabular}

Note: Growth in total population and growth in working age population are calculated for the years 1965 to 1990 and 1990 to 1995.

The data for total years of education are for 1965 and 1990.

Source: Demographic data are taken from UN 1994. GDP and school enrollment data are taken from the Penn World Tables, and include a smaller sample of countries 


\section{Table 10: Variable Definitions and Selected Descriptive Statistics}

\begin{tabular}{|l|c|c|c|c|}
\hline \multicolumn{1}{|c|}{ Definition (Source) } & Mean & $\begin{array}{l}\text { Standard } \\
\text { Deviation }\end{array}$ & Min & Max \\
\hline $\begin{array}{l}\text { Average growth rate of GDP per capita 1965-1990. } \\
\text { Source: Penn World Tables 5.6. }\end{array}$ & 1.93 & 1.83 & -2.24 & 7.41 \\
\hline $\begin{array}{l}\text { GDP per capita 1965 (purchasing power parity) in 1985 } \\
\text { dollars. Source: Penn World Tables 5.6 }\end{array}$ & 3430 & 2986 & 412 & 11638 \\
\hline $\begin{array}{l}\text { Proportion of land area in the tropics. Source: Gallup, } \\
\text { Sachs and Mellinger (1998). }\end{array}$ & 0.50 & 0.49 & 0.00 & 1.00 \\
\hline $\begin{array}{l}\text { Dichotomous variable taking the value 1 if the country is } \\
\text { landlocked. Source: Gallup, Sachs and Mellinger (1998). }\end{array}$ & 0.13 & 0.34 & 0.00 & 1.00 \\
\hline $\begin{array}{l}\text { Average population growth rate, } \\
\text { 1965-90. Source: World Bank, World Tables. }\end{array}$ & 1.92 & 1.04 & 0.17 & 4.27 \\
\hline $\begin{array}{l}\text { Average growth rate of working age population 1965-90. } \\
\text { Source: World Bank, World Tables. }\end{array}$ & 2.18 & 1.07 & 0.25 & 4.20 \\
\hline $\begin{array}{l}\text { Ratio of working age to total population in 1965. Source: } \\
\text { World Bank, World Tables. }\end{array}$ & 0.56 & 0.06 & 0.47 & 0.68 \\
\hline $\begin{array}{l}\text { Average years of secondary education of population } \\
\text { aged 15 to 65 in 1965. Source: Barro and Lee (1995). }\end{array}$ & 0.81 & 0.76 & 0.01 & 3.51 \\
\hline $\begin{array}{l}\text { Life expectancy in 1965. Source: World Bank, World } \\
\text { Tables }\end{array}$ & 58.7 & 11.7 & 33.5 & 74.1 \\
\hline $\begin{array}{l}\text { Percentage of years country is open between 1965 and } \\
\text { 1990. Source: Sachs and Warner (1995). }\end{array}$ & 0.46 & 0.45 & 0.0 & 1.0 \\
\hline $\begin{array}{l}\text { Index of the quality of government institutions. Source: } \\
\text { Knack and Keefer (1995). }\end{array}$ & 6.10 & 2.40 & 2.27 & 9.98 \\
\hline $\begin{array}{l}\text { Working age population density (per km }{ }^{2} \text { )in the coastal } \\
\text { areas. Source: Gallup, Sachs and Mellinger (1998). }\end{array}$ & 174.9 & 568.7 & 0.0 & 3729.3 \\
\hline $\begin{array}{l}\text { Working age population density (per km }{ }^{2} \text { ) in the inland } \\
\text { areas. Source: Gallup, Sachs and Mellinger (1998) }\end{array}$ & 56.1 & 109.1 & 0.0 & 537.0 \\
\hline
\end{tabular}


Table 11: Countries Used in Cross Country Regressions

\begin{tabular}{|c|c|}
\hline 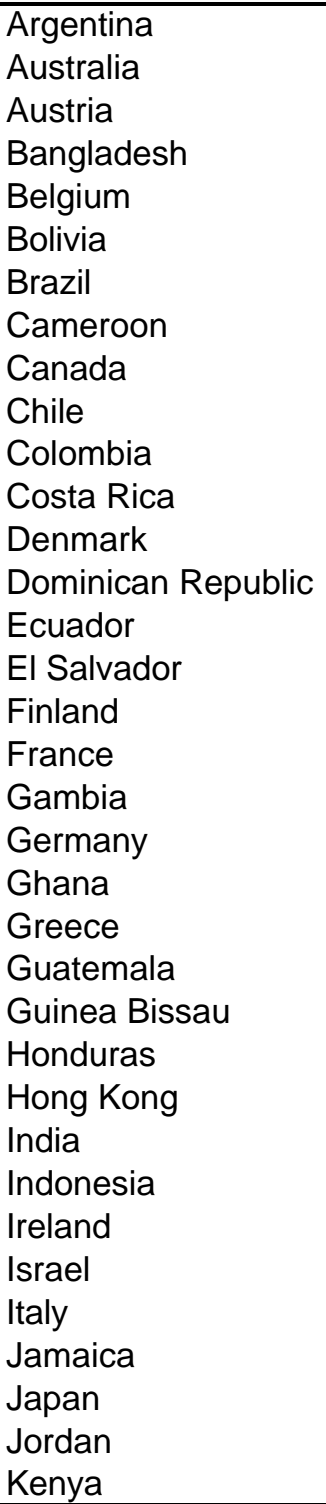 & $\begin{array}{l}\text { Korea,Republic of } \\
\text { Malawi } \\
\text { Malaysia } \\
\text { Mali } \\
\text { Mexico } \\
\text { Netherlands } \\
\text { New Zealand } \\
\text { Nicaragua } \\
\text { Norway } \\
\text { Pakistan } \\
\text { Papua New Guinea } \\
\text { Paraguay } \\
\text { Peru } \\
\text { Philippines } \\
\text { Portugal } \\
\text { Senegal } \\
\text { Sierra Leone } \\
\text { Singapore } \\
\text { South Africa } \\
\text { Spain } \\
\text { Sri Lanka } \\
\text { Sweden } \\
\text { Switzerland } \\
\text { Syrian Arab Rep. } \\
\text { Thailand } \\
\text { Trinidad \& Tobago } \\
\text { Tunisia } \\
\text { Turkey } \\
\text { Uganda } \\
\text { United Kingdom } \\
\text { United States } \\
\text { Uruguay } \\
\text { Venezuela } \\
\text { Zambia } \\
\text { Zimbabwe } \\
\text { Sagiand }\end{array}$ \\
\hline
\end{tabular}

Note: Different countries are used in the shift-share analysis and the panel regressions. These are available from the authors on request. 